Bond University

Research Repository

\title{
Interventions for erythropoietin-resistant anaemia in dialysis patients
}

Badve, Sunil V; Beller, Elaine M; Cass, Alan; Francis, Daniel P; Hawley, Carmel; Macdougall, lain C; Perkovic, Vlado; Johnson, David W

Published in:

Cochrane Database of Systematic Reviews

DOI:

10.1002/14651858.CD006861.pub3

Licence:

Other

Link to output in Bond University research repository.

Recommended citation(APA):

Badve, S. V., Beller, E. M., Cass, A., Francis, D. P., Hawley, C., Macdougall, I. C., Perkovic, V., \& Johnson, D. W. (2013). Interventions for erythropoietin-resistant anaemia in dialysis patients. Cochrane Database of Systematic Reviews, (8), CD006861. [006861]. https://doi.org/10.1002/14651858.CD006861.pub3

\section{General rights}

Copyright and moral rights for the publications made accessible in the public portal are retained by the authors and/or other copyright owners and it is a condition of accessing publications that users recognise and abide by the legal requirements associated with these rights.

For more information, or if you believe that this document breaches copyright, please contact the Bond University research repository coordinator. 


\section{(E) Cochrane Library}

Cochrane Database of Systematic Reviews

\section{Interventions for erythropoietin-resistant anaemia in dialysis patients (Review)}

Badve SV, Beller EM, Cass A, Francis DP, Hawley C, Macdougall IC, Perkovic V, Johnson DW

Badve SV, Beller EM, Cass A, Francis DP, Hawley C, Macdougall IC, Perkovic V, Johnson DW.

Interventions for erythropoietin-resistant anaemia in dialysis patients.

Cochrane Database of Systematic Reviews 2013, Issue 8. Art. No.: CD006861.

DOI: 10.1002/14651858.CD006861.pub3.

www.cochranelibrary.com 
TABLE OF CONTENTS

HEADER . . . . . . . . . . . . . . . . . . . . . . . . . . . . . . . . . . . . 1

ABSTRACT . . . . . . . . . . . . . . . . . . . . . . . . . . . . . . . . . . . . . . .

PLAIN LANGUAGE SUMMARY . . . . . . . . . . . . . . . . . . . . . . . . . . . . . . . . . . . . 2

BACKGROUND . . . . . . . . . . . . . . . . . . . . . . . . . . . . . . . . . . . . . .

OBJECTIVES . . . . . . . . . . . . . . . . . . . . . . . . . . . . . . . . . . . . . .

METHODS . . . . . . . . . . . . . . . . . . . . . . . . . . . . . . . . . . . . . .

RESULTS . . . . . . . . . . . . . . . . . . . . . . . . . . . . . . . . . . . . . 5

Figure 1. . . . . . . . . . . . . . . . . . . . . . . . . . . . . . . . . . . 5

DISCUSSION . . . . . . . . . . . . . . . . . . . . . . . . . . . . . . . . . . . . .

AUTHORS' CONCLUSIONS . . . . . . . . . . . . . . . . . . . . . . . . . . . . . . . . . . 8

ACKNOWLEDGEMENTS . . . . . . . . . . . . . . . . . . . . . . . . . . . . . . . . . . . .

REFERENCES . . . . . . . . . . . . . . . . . . . . . . . . . . . . . . . . . . . . . . 8

CHARACTERISTICS OF STUDIES . . . . . . . . . . . . . . . . . . . . . . . . . . . . . . . . . . . . . .

DATA AND ANALYSES . . . . . . . . . . . . . . . . . . . . . . . . . . . . . . . . . . . . . . . . . . . . . . . . .

Analysis 1.1. Comparison 1 Clinical outcomes, Outcome 1 Non-fatal cardiovascular events. . . . . . . . . . . . 26

Analysis 1.2. Comparison 1 Clinical outcomes, Outcome 2 Hospitalisations. . . . . . . . . . . . . . . . . . 26

Analysis 2.1. Comparison 2 Haematology and biochemistry results, Outcome 1 Haemoglobin. . . . . . . . . . . 27

Analysis 2.2. Comparison 2 Haematology and biochemistry results, Outcome 2 Haematocrit. .... . . . . $\quad 27$

Analysis 2.3. Comparison 2 Haematology and biochemistry results, Outcome 3 Transferin saturation (TSAT). $\quad . \quad$. 28

Analysis 2.4. Comparison 2 Haematology and biochemistry results, Outcome 4 Ferritin. . . . . . . . . . . . . . $\quad$. 28

Analysis 2.5. Comparison 2 Haematology and biochemistry results, Outcome 5 Haemoglobin content in reticulocytes

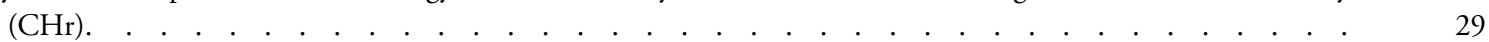

Analysis 2.6. Comparison 2 Haematology and biochemistry results, Outcome 6 C-reactive protein. . . . . . . . 29

Analysis 3.1. Comparison 3 ESA and IV iron doses, Outcome 1 EPO dose. . . . . . . . . . . . . . . . . . . . . 30

Analysis 3.2. Comparison 3 ESA and IV iron doses, Outcome 2 IV Iron. . . . . . . . . . . . . . . . . . . . . 30

ADDITIONAL TABLES . . . . . . . . . . . . . . . . . . . . . . . . . . . . . . . . . . . . . 30

APPENDICES . . . . . . . . . . . . . . . . . . . . . . . . . . . . . . . . . . . . . . . . . .

CONTRIBUTIONS OF AUTHORS . . . . . . . . . . . . . . . . . . . . . . . . . . . . . . . . . . . . . . . 36

DECLARATIONS OF INTEREST . . . . . . . . . . . . . . . . . . . . . . . . . . . . . . . . . . . . . 36

SOURCES OF SUPPORT . . . . . . . . . . . . . . . . . . . . . . . . . . . . . . . . . . . . . . . . 36

DIFFERENCES BETWEEN PROTOCOL AND REVIEW . . . . . . . . . . . . . . . . . . . . . . . . . . . . .

INDEX TERMS . . . . . . . . . . . . . . . . . . . . . . . . . . . . . . . . . . . . . . . . . . . . . . . . . . .

Interventions for erythropoietin-resistant anaemia in dialysis patients (Review)

Copyright $\odot 2013$ The Cochrane Collaboration. Published by John Wiley \& Sons, Ltd. 


\title{
[Intervention Review] \\ Interventions for erythropoietin-resistant anaemia in dialysis patients
}

\author{
Sunil V Badve ${ }^{1}$, Elaine M Beller ${ }^{2}$, Alan Cass ${ }^{3}$, Daniel P Francis ${ }^{4}$, Carmel Hawley ${ }^{1}$, Iain C Macdougall ${ }^{5}$, Vlado Perkovic ${ }^{3}$, David W \\ Johnson $^{1}$ \\ ${ }^{1}$ Department of Nephrology, Princess Alexandra Hospital, Woolloongabba, Australia. ${ }^{2}$ Faculty of Health Sciences and Medicine, Bond \\ University, Gold Coast, Australia. ${ }^{3}$ Renal and Metabolic Division, The George Institute for Global Health, Camperdown, Australia. \\ ${ }^{4}$ Central Regional Services, Division of the CHO, Queensland Health, Stafford DC, Australia. ${ }^{5}$ Renal Unit, King's College Hospital, \\ London, UK
}

Contact address: Sunil V Badve, Department of Nephrology, Princess Alexandra Hospital, Woolloongabba, QLD, 4102, Australia. sunil_badve@health.qld.gov.au.

Editorial group: Cochrane Kidney and Transplant Group.

Publication status and date: New, published in Issue 8, 2013.

Citation: Badve SV, Beller EM, Cass A, Francis DP, Hawley C, Macdougall IC, Perkovic V, Johnson DW. Interventions for erythropoietin-resistant anaemia in dialysis patients. Cochrane Database of Systematic Reviews 2013, Issue 8. Art. No.: CD006861. DOI: 10.1002/14651858.CD006861.pub3.

Copyright (C) 2013 The Cochrane Collaboration. Published by John Wiley \& Sons, Ltd.

\begin{abstract}
A B S T R A C T
Background

People living with end-stage kidney disease (ESKD) often develop anaemia. Erythropoiesis-simulating agents (ESAs) are often given to people living with ESKD to maintain haemoglobin at a level to minimise need for transfusion. However, about $5 \%$ to $10 \%$ of patients with ESKD exhibit resistance to ESAs, and observational studies have shown that patients requiring high doses of ESA are at increased risk of mortality.
\end{abstract}

\section{Objectives}

This review aimed to study the effects of interventions for the treatment of ESA-resistant anaemia in people with ESKD.

\section{Search methods}

We searched the Cochrane Central Register of Controlled Trials (CENTRAL), MEDLINE and EMBASE for randomised controlled trials (RCT) that involved participants with ESKD on dialysis or who were pre-dialysis patients with chronic kidney disease (stage 5). Date of last search: April 2013.

\section{Selection criteria}

ESA resistance was defined as failure to achieve or maintain haemoglobin/haematocrit levels within the desired target range despite appropriate ESA doses (erythropoietin $\geq 450 \mathrm{U} / \mathrm{kg} / \mathrm{wk}$ intravenously or $\geq 300 \mathrm{U} / \mathrm{kg} / \mathrm{wk}$ subcutaneously; darbepoetin $\geq 1.5 \mu \mathrm{g} / \mathrm{kg} /$ wk) in people who were not nutritionally deficient, or who had haematological or bleeding disorders. Extended inclusion criteria for ESA hyporesponsive state were: erythropoietin dose $\geq 300 \mathrm{U} / \mathrm{kg} / \mathrm{wk}$ and $\geq 150 \mathrm{U} / \mathrm{kg} / \mathrm{wk}$ for intravenous administration; or $\geq 200 \mathrm{U} /$ $\mathrm{kg} / \mathrm{wk}$ and $\geq 100 \mathrm{U} / \mathrm{kg} / \mathrm{wk}$ for subcutaneous administration; or darbepoetin dose $\geq 1.0 \mu \mathrm{g} / \mathrm{kg} / \mathrm{wk}$ ).

\section{Data collection and analysis}

Two authors independently assessed study quality and extracted data. Statistical analyses were performed using a random effects model and results expressed as risk ratio (RR) or mean difference (MD) with $95 \%$ confidence intervals (CI).

Interventions for erythropoietin-resistant anaemia in dialysis patients (Review)

Copyright $\odot 2013$ The Cochrane Collaboration. Published by John Wiley \& Sons, Ltd. 


\section{Main results}

Titles and abstracts of 521 records were screened, of which we reviewed 99 from the full text. Only two studies matched our inclusion criteria. One study compared intravenous vitamin $\mathrm{C}$ versus no study medication for six months in $42 \mathrm{ESKD}$ patients on haemodialysis who required intravenous erythropoietin (dose $\geq 450 \mathrm{U} / \mathrm{kg} / \mathrm{wk}$ ). The other included study compared high-flux dialyser versus lowflux dialyser for six months in 48 haemodialysis patients who required subcutaneous erythropoietin (dose $\geq 200 \mathrm{U} / \mathrm{kg} / \mathrm{wk}$ ). Because interventions differed, data could not be combined for quantitative meta-analysis.

\section{Authors' conclusions}

There was inadequate evidence identified to inform recommendation of any intervention to ameliorate ESA hyporesponsiveness. Adequately powered RCTs are required to establish the safety and efficacy of interventions to improve responsiveness to ESA therapy.

\section{PLAIN LANGUAGE SUMMARY}

\section{Interventions for anaemia in dialysis patients who are resistant to erythropoietin}

Many people with chronic kidney disease (CKD) who are on dialysis develop anaemia (too few or poor quality red blood cells). Drugs in the erythropoiesis-stimulating family increase the production of red blood cells to resolve anaemia. Although ESAs have been highly beneficial for many, about $10 \%$ of people get either low or no benefit from treatment. Inability to control and stabilise anaemia can lead to poor rates of survival and increased risk of stroke so it is important to find effective treatment to manage anaemia in people who do not respond adequately to ESA therapy.

We searched the literature to find evidence about how best to treat people who do not benefit from ESA treatment. We found two studies: one that assessed intravenous vitamin $\mathrm{C}$ and another that looked at high-flux dialyser fluids as possible therapies. These studies were small (total of 90 participants) and were selective: they included haemodialysis, but not peritoneal dialysis, patients. This meant that the results of these studies could not be applied to all people with CKD on dialysis who were receiving ESA therapy. The lack of evidence meant that we could not determine or recommend an alternate treatment for people who do not respond to ESA.

More powerful and rigorous studies are needed to systematically assess all therapies that are aimed to treat people who do not respond to ESA therapy. Until such evidence is available, no therapy can be confidently recommended for this problem.

\section{B A C K G R O U N D}

\section{Description of the condition}

Erythropoiesis-stimulating agents (ESAs) are perhaps the most rigorously tested group of drugs in nephrology. Since the introduction of ESAs, there have been substantial reductions in blood transfusion requirements among patients living with chronic kidney disease (CKD) (Eschbach 1989).

A systematic review of 14 randomised controlled and uncontrolled trials in pre-dialysis CKD patients demonstrated that treatment of anaemia with ESAs improved energy levels and physical function (Gandra 2010). Unfortunately, a considerable proportion of these patients exhibited suboptimal haematologic response to ESA ( Benz 1999; Valderrabano 1996).
There are several known causes of suboptimal response to ESA. These include deficiencies in iron, vitamin $\mathrm{B}_{12}$, and folate; infection, chronic inflammatory state, neoplasia, severe hyperparathyroidism, aluminium intoxication, inadequate dialysis, myelosuppressive agents, haemoglobinopathies, myelodysplasia and antibody-mediated pure red cell aplasia (Macdougall 2002). However, after excluding these conditions it was found that about $10 \%$ of patients exhibit ESA-resistant anaemia, and these people have greatly increased rates of morbidity and mortality (Kausz 2005; Macdougall 2002; Zhang 2004).

ESA treatment used to target high haemoglobin levels in people with CKD is associated with deleterious (Phrommintikul 2007) or neutral (Palmer 2010) impacts on survival and increased risks of stroke, vascular access thrombosis and hypertension without any reduction in cardiovascular events (Palmer 2010; Phrommintikul 2007). 
Although RCTs and systematic reviews consistently show more harm than benefit associated with higher haemoglobin targets for ESA treatment (Besarab 1998; Palmer 2010; Pfeffer 2009; Phrommintikul 2007; Singh 2006), secondary analyses of RCTs and observational studies have demonstrated that poor response to ESA treatment rather than achieved high haemoglobin, may be responsible for the observed suboptimal outcomes in people with CKD (Kilpatrick 2008; Messana 2009; Regidor 2006; Solomon 2010; Szczech 2008).

These studies also showed that patients who required higher doses of ESA experienced increased mortality at any haemoglobin level, and that patients who achieve target haemoglobin levels had better outcomes than those who did not (Badve 2011). Therefore, therapies targeting ESA resistance could be a promising treatment strategy in CKD anaemia management.

\section{Description of the intervention}

Although there is no effective treatment for patients with ESAresistant anaemia at present, a number of interventions such as Lcarnitine, ascorbic acid, oxpentifylline, androgens and statins have been investigated.

\section{O B J E C T IVES}

This review looked at the benefits and harms of any intervention used in the treatment of ESA-resistant anaemia in people with end-stage kidney disease (ESKD) who were receiving dialysis.

\section{METHODS}

\section{Criteria for considering studies for this review}

\section{Types of studies}

All randomised controlled trials (RCTs) and quasi-RCTs (studies in which allocation to treatment was obtained by alternation, use of alternate medical records, date of birth or other predictable methods) looking at interventions for the treatment of ESA-resistant anaemia in people with ESKD were included in our review.

\section{Types of participants}

- Adults and children with ESKD (chronic kidney disease (CKD) stage 5 or pre-dialysis) or those receiving dialysis (either haemodialysis or peritoneal dialysis).
- Adults and children with ESKD receiving any type of ESA for anaemia (anaemia defined as haemoglobin $<110 \mathrm{~g} / \mathrm{L}$ or as defined by the investigators).

- Evidence of ESA resistance, defined as failure to achieve or maintain target range haemoglobin/haematocrit levels in spite of appropriate ESA doses (erythropoietin $\geq 450 \mathrm{U} / \mathrm{kg} / \mathrm{wk}$ intravenous administration or $\geq 300 \mathrm{U} / \mathrm{kg} / \mathrm{wk}$ for subcutaneous administration or darbepoetin $\geq 1.5 \mu \mathrm{g} / \mathrm{kg} / \mathrm{wk}$ ) (KDOQI 2001; Locatelli 2004). This inclusion criterion was amended after publication of the protocol of this systematic review because only one eligible study was found. Extended inclusion criteria were studies that defined ESA-hyporesponsive state as failure to achieve or maintain target haemoglobin/haematocrit in spite of the following doses of the ESA: erythropoietin dosage $\geq 300$ and $\geq 150 \mathrm{U} / \mathrm{kg} / \mathrm{wk}$ for IV administration; or $\geq 200$ and $\geq 100 \mathrm{U} /$ $\mathrm{kg} / \mathrm{wk}$ for subcutaneous administration; or darbepoetin dosage $\geq 1.0 \mu \mathrm{g} / \mathrm{kg} / \mathrm{wk}$ ).

- All known causes of ESA-resistance (such as iron deficiency, vitamin $\mathrm{B}_{12}$ deficiency, folate deficiency, infection, chronic inflammatory state, neoplasia, severe hyperparathyroidism, aluminium intoxication, inadequate dialysis, myelosuppressive agents, haemoglobinopathies, myelodysplasia and antibodymediated pure red cell aplasia) must have been ruled out.

- Studies performed in kidney transplant recipients were excluded.

\section{Types of interventions}

Any potential intervention used to treat ESA-resistance, such as L-carnitine, ascorbic acid, oxpentifylline, androgens, and statins, were included in this review.

\section{Types of outcome measures}

- All-cause mortality

- Cardiovascular mortality

- Non-fatal cardiovascular events

- Number of patients achieving target haemoglobin/ haematocrit

- Difference or changes in haemoglobin or haematocrit between intervention and control groups at study end

- Difference or changes in ESA dose between intervention and control groups at study end

- Blood transfusion requirements

- Quality of life

- Hospitalisation

- Any reported adverse events

- Differences or changes in inflammatory biomarkers between intervention and control groups at study end

- Differences or changes in biomarkers of oxidative stress between intervention and control groups at study end. 


\section{Search methods for identification of studies}

\section{Electronic searches}

We searched the Cochrane Renal Group's specialised register 18th March 2013 through contact with the Trials' Search Co-ordinator using search terms relevant to this review.

The Cochrane Renal Group's Specialised Register contains studies identified from:

1. Monthly searches of the Cochrane Central Register of Controlled Trials (CENTRAL)

2. Weekly searches of MEDLINE OVID SP

3. Handsearching of renal-related journals and the proceedings of major renal conferences

4. Searching of the current year of EMBASE OVID SP

5. Weekly current awareness alerts for selected renal journals

6. Searches of the International Clinical Trials Register (ICTRP) Search Portal and ClinicalTrials.gov.

Studies contained in the specialised register are identified through search strategies for CENTRAL, MEDLINE and EMBASE based on the scope of the Cochrane Renal Group. Details of these strategies, as well as a list of handsearched journals, conference proceedings and current awareness alerts, are available in the specialised register section of information about the Cochrane Renal Group. See Appendix 1 for search terms used in strategies for this review.

\section{Searching other resources}

1. Reference lists of clinical practice guidelines, review articles and relevant studies.

2. Relevant missing or incomplete or unpublished data from the clinical studies were requested from the respective investigators/ authors by written correspondence.

\section{Data collection and analysis}

\section{Selection of studies}

The search strategy described was used to obtain titles and abstracts of studies relevant to the review. Titles and abstracts were screened independently by three authors, who discarded studies that were not applicable. However, studies and reviews that potentially included relevant data or study information were retained initially. The same three authors independently assessed retrieved abstracts, and if necessary the full text, of these studies to determine which studies satisfied the inclusion criteria.

\section{Data extraction and management}

Data extraction was carried out independently by two authors using standard data extraction forms. Studies reported in nonEnglish language journals was to be translated before assessment. Where more than one publication of one study existed, reports were grouped together and the publication with the most complete data was used in the analyses. Where relevant outcomes were only published in earlier versions, these data were used. Any discrepancies between published versions was to be highlighted. Disagreements were resolved by consensus.

\section{Assessment of risk of bias in included studies}

The following items will be independently assessed by two authors using the risk of bias assessment tool (Higgins 2011) (see Appendix 2).

- Was there adequate sequence generation (selection bias)?

- Was allocation adequately concealed (selection bias)?

- Was knowledge of the allocated interventions adequately prevented during the study (detection bias)?

- Participants and personnel

- Outcome assessors

- Were incomplete outcome data adequately addressed (attrition bias)?

- Are reports of the study free of suggestion of selective outcome reporting (reporting bias)?

- Was the study apparently free of other problems that could put it at a risk of bias?

\section{Measures of treatment effect}

For dichotomous outcomes (all-cause mortality, cardiovascular mortality, non-fatal cardiovascular events, number of patients achieving haemoglobin/haematocrit targets, number of patients requiring hospitalisation, number of patients requiring blood transfusions, number of patients with medication-related adverse effects), results were expressed as risk ratios (RR) with $95 \%$ confidence intervals (CI). For continuous data (haemoglobin, haematocrit, iron studies, ESA dosage, iron dosage, hospitalisation days, quality of life scores, inflammatory biomarkers, biomarkers of oxidative stress), results were expressed as mean difference (MD).

\section{Dealing with missing data}

We planned that any further information required from the original author was to be requested by written correspondence, and any relevant information obtained was be included in the review. Evaluation of important numerical data such as screened, randomised patients as well as intention-to-treat (ITT), as-treated and perprotocol (PP) population was performed. 


\section{Assessment of heterogeneity}

Heterogeneity was to be analysed using a $\mathrm{Chi}^{2}$ test on $\mathrm{N}-1$ degrees of freedom, with an alpha of 0.05 used for statistical significance and with the $\mathrm{I}^{2}$ test (Higgins 2003). $\mathrm{I}^{2}$ values of $25 \%, 50 \%$ and $75 \%$ correspond to low, medium and high levels of heterogeneity.

\section{Data synthesis}

Data were to be pooled using the random-effects model.

RE S U L T S

\section{Description of studies}

\section{Results of the search}

We identified 533 abstracts using the search strategy described (Figure 1). After screening titles and abstracts, 99 reports were selected for full text review. Only two studies (Attallah 2006; Ayli 2004) met our inclusion criteria, and of these, one investigated our extended inclusion criterion of ESA hyporesponsive state (Ayli 2004).

Figure I. The PRISMA flow chart showing selection of studies

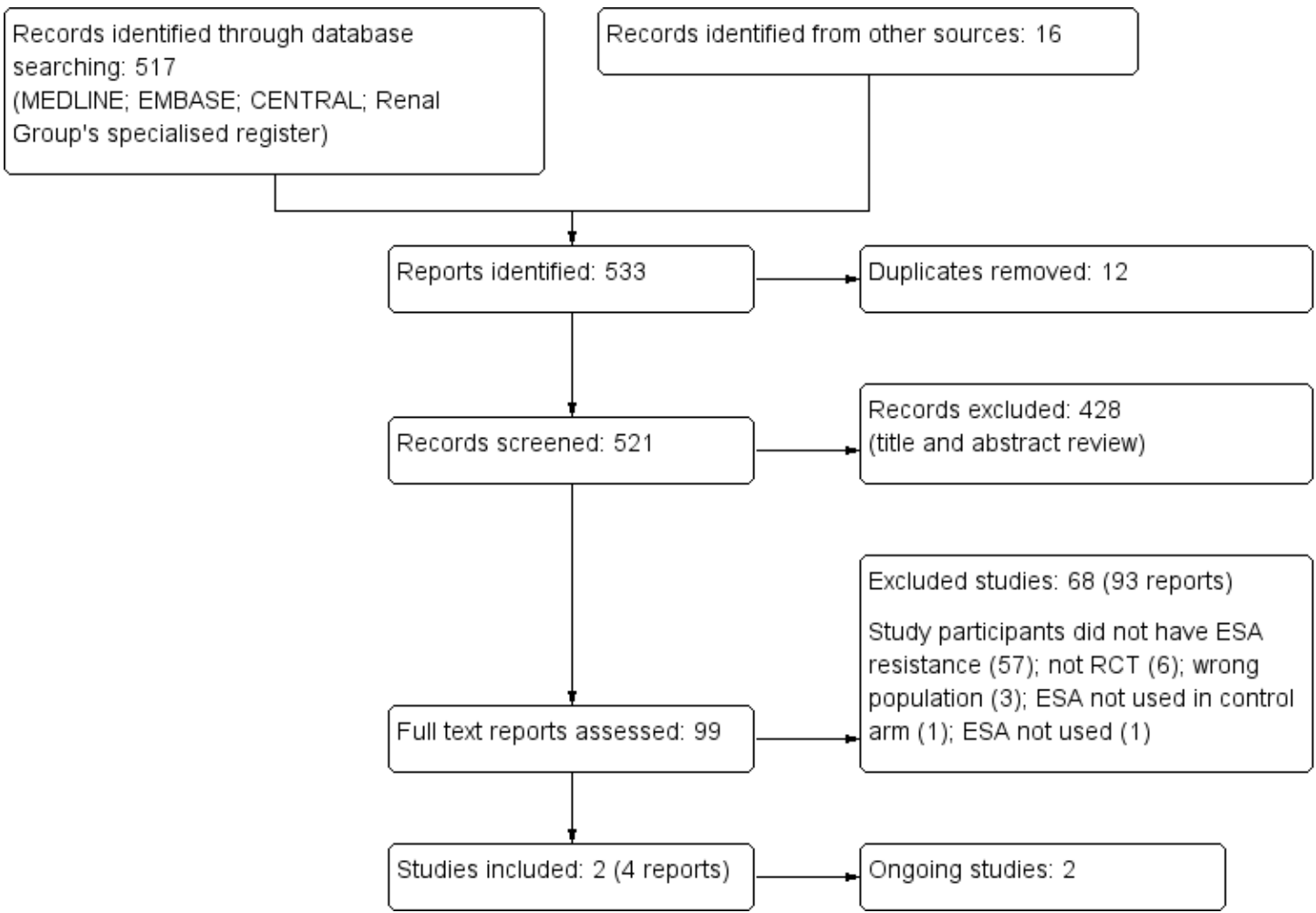

We considered inclusion of a study that applied our extended inclusion criterion of ESA-hyporesponsive state (Sezer 2002). In this study, participants in both arms received the investigational drug (vitamin C) in the first study phase (eight weeks). Nonresponders were excluded at the end of the first phase. During the second phase, remaining participants were randomised to receive either the investigational drug at a reduced frequency or no study drug for another eight weeks. Since the investigators did not define 'non-responder', and there was a strong possibility of carry over effect of vitamin $\mathrm{C}$ administered before randomisation, the study was excluded from this systematic review. 


\section{Included studies}

Two studies met our inclusion criteria.

- Attallah 2006 enrolled 42 haemodialysis patients and compared IV vitamin $\mathrm{C}$ given at each dialysis session to no treatment.

- Ayli 2004 enrolled 48 haemodialysis patients and compared high-flux versus low-flux dialysis membranes

\section{Excluded studies}

We excluded 68 studies after full-text review: six were not randomised; 58 included participants who did not have ESA resistance; two included iron deficient participants who lacked true ESA resistance; and two studies did not use ESA in the control arm.

\section{Risk of bias in included studies}

\section{Allocation}

Allocation concealment was unclear in both included studies ( Attallah 2006; Ayli 2004).

\section{Blinding}

It was unclear if in Attallah 2006, an open-label study, outcome assessors were blinded. Likewise, blinding of participants, investigators or outcome assessors in Ayli 2004 was also unclear.

\section{Incomplete outcome data}

All participants were followed for the entire study period and accounted for in both studies. Attrition bias arising from incomplete outcome reporting was deemed to be low risk.

\section{Selective reporting}

Neither study reported proportions of participants in each study arm who achieved haemoglobin target levels. The risk of reporting bias in both was therefore unclear.

\section{Other potential sources of bias}

Both studies were judged to be at high risk of other potential sources of bias due to single-centre study design and exclusion of patients on peritoneal dialysis.

\section{Effects of interventions}

Treatments differed in the interventional arms of Attallah 2006 and Ayli 2004 (vitamin C and high-flux dialyser). Therefore, data were not combined and results are presented separately.

\section{Clinical outcomes}

\section{All-cause and cardiovascular mortality}

No deaths were reported in either study.

\section{Non-fatal cardiovascular events}

Attallah 2006 reported no significant difference in the risk of nonfatal cardiovascular events between study arms (Analysis 1.1: RR $0.79,95 \%$ CI 0.20 to 3.09 ).

Ayli 2004 did not report non-fatal cardiovascular events.

\section{Participants achieving target haemoglobin or haematocrit}

Neither study reported the proportions of participants who achieved target haemoglobin or haematocrit levels.

\section{Requirement of blood transfusions}

Attallah 2006 reported no participants included in the final analysis required blood transfusion. However, one participant from the control group was excluded from the final analysis because of the need for a blood transfusion due to a significant upper gastrointestinal bleed.

Ayli 2004 did not report need for blood transfusion.

\section{Hospitalisations}

Attallah 2006 reported no significant difference in the risk of hospitalisations between the groups (Analysis 1.2: RR 0.96, 95\% CI 0.56 to 1.66$)$.

Ayli 2004 did not report hospitalisations.

\section{Medication-related adverse events}

Attallah 2006 reported there were no adverse events noted in either group. Ayli 2004 did not report adverse events.

\section{Haematology and biochemistry results}

\section{Haemoglobin}

Both studies reported significantly higher haemoglobin levels in the treatment groups compared to the control groups (Analysis 2.1.1: MD 0.9 g/dL, 95\% CI 0.38 to 1.42 ; Attallah 2006); ( Analysis 2.1.2: MD 1.9 g/dL, 95\% CI 1.64 to 2.16; Ayli 2004). 


\section{Haematocrit}

Attallah 2006 did not report data on participants' haematocrit levels. Ayli 2004 reported that among interventional arm participants haematocrit was significantly higher than those in the control arm (Analysis 2.2: MD 6.8\%, 95\% CI 5.67 to 7.93 ).

\section{Transferin saturation (TSAT)}

Attallah 2006 reported that TSAT was significantly higher in interventional than control arm participants (Analysis 2.3.1: MD $8.00 \%, 95 \%$ CI 6.22 to 9.78). There was no significant difference in TSAT between study arms reported by Ayli 2004 (Analysis 2.3.2: MD $1.30 \%$, $95 \%$ CI -3.99 to 6.59 ).

\section{Ferritin}

Attallah 2006 reported that ferritin was significantly higher among interventional than control arm participants (Analysis 2.4.1: MD $8.00 \mathrm{ng} / \mathrm{mL}, 95 \% \mathrm{CI}-85.51$ to 101.51$)$. There was no significant difference between study arms reported by Ayli 2004 (Analysis 2.4.2: MD $-3.00 \mathrm{ng} / \mathrm{mL}, 95 \% \mathrm{CI}-43.46$ to 37.46$)$.

\section{Haemoglobin content in reticulocytes ( $\mathrm{CHr}$ )}

Attallah 2006 reported that $\mathrm{CHr}$ was significantly higher in interventional than control arm participants (Analysis 2.5: MD 0.90 pg, 95\% CI 0.40 to 1.40 ). Ayli 2004 did not report CHr data.

\section{Inflammatory biomarkers: C-reactive protein}

Attallah 2006 reported C-reactive protein was significantly lower in vitamin $\mathrm{C}$ group compared to the control group (Analysis 2.6.1: $\mathrm{MD}-1.20 \mathrm{mg} / \mathrm{dL}, 95 \% \mathrm{CI}-1.69$ to -0.71$)$. There was no significant difference between study arms in C-reactive protein reported by Ayli 2004 (Analysis 2.6.2: MD -0.4 mg/dL, 95\% CI -3.0 to 2.2 ).

\section{Markers of oxidative stress}

Neither Attallah 2006 nor Ayli 2004 reported markers of oxidative stress.

\section{ESA and intravenous iron doses}

\section{ESA dose}

Attallah 2006 reported ESA was significantly lower in vitamin c group compared to the control group (Analysis 3.1: MD -18 U/ $\mathrm{kg} / \mathrm{wk}, 95 \%$ CI -35.62 to -0.38 ). Ayli $2004 \mathrm{did}$ not report data on ESA dose.

\section{Intravenous iron therapy dose}

Attallah 2006 reported that there was no significant difference in intravenous iron therapy dose between the study arms (Analysis 3.2: MD $-0.20 \mathrm{mg} / \mathrm{wk}, 95 \% \mathrm{CI}-16.15$ to 15.75 ). Ayli $2004 \mathrm{did}$ not report on intravenous iron therapy dose.

\section{Other outcomes}

\section{Hospitalisation days}

Neither Attallah 2006 nor Ayli 2004 reported numbers of hospitalisation days.

\section{Quality of life scores}

Neither Attallah 2006 nor Ayli 2004 reported quality of life scores.

\section{DISCUSSION}

The results of this systematic review highlight the absence of adequately powered randomised controlled trials (RCT) examining the effect of various interventions to treat ESA hyporesponsiveness. We found that there was insufficient and inadequate evidence to recommend any intervention to ameliorate ESA-hyporesponsiveness.

We identified only one RCT that defined ESA-hyporesponsiveness as intravenous EPO dose $\geq 450 \mathrm{U} / \mathrm{kg} / \mathrm{wk}$ (Attallah 2006). When inclusion criteria were extended to include subcutaneous EPO dose $\geq 200 \mathrm{U} / \mathrm{kg} / \mathrm{wk}$, another study, Ayli 2004, was found to be eligible for inclusion.

In relation to intravenous vitamin C therapy, Attallah 2006 demonstrated increases in haemoglobin, haemoglobin content in reticulocytes, and transferin saturation; and reductions in erythropoietin dose and C-reactive protein. Ayli 2004 reported that use of high-flux dialyser for six months was associated with improvement in haemoglobin, but there was no effect on C-reactive protein or iron studies. Both Attallah 2006 and Ayli 2004 were single-centre studies and included 42 and 48 participants respectively. The studies included only haemodialysis patients, and hence, results may not be generalisable to CKD patients not yet on dialysis, those on peritoneal dialysis, or in settings where patient populations differ.

There is no single widely accepted definition of ESA resistance. KDOQI has defined ESA resistance as failure to achieve haemoglobin $11 \mathrm{~g} / \mathrm{dL}$ with ESA dose equivalent to epoetin greater than $500 \mathrm{IU} / \mathrm{kg} / \mathrm{wk}$ (KDOQI 2006). Publication of KDIGO anaemia guidelines is expected this year. As yet, there have been no RCTs performed explicitly in patients with ESA resistance as defined by KDOQI. 
In the Normal Haematocrit Cardiac Trial, more participants in the normal haematocrit group reached the primary endpoint (composite of death and non-fatal myocardial infarction) with mean erythropoietin doses of $440 \mathrm{IU} / \mathrm{kg} / \mathrm{wk}$, which is lower than the KDOQI definition (Besarab 1998). In the CHOIR trial, it was reported that ESA dose > 20,000 IU/wk was associated with increased risk of death, congestive heart failure, stroke, and myocardial infarction (Szczech 2008).

Several observational studies have suggested a linear association between ESA dose and adverse outcomes (Brookhart 2010; Messana 2009; Regidor 2006; Zhang 2004; Zhang 2009). There is substantial variability in the reporting of ESA dose, such as IU/kg/wk, IU/ wk, or ESA dose normalised to haemoglobin level. Therefore, the current KDOQI definition of ESA resistance needs to be revised, and the new definition should be based on ESA-resistance index (ERI) rather than ESA dose to bring uniformity in reporting.

The revised inclusion criteria of the ongoing HERO Study are ESA-resistance index $\geq 1.0 \mathrm{IU} / \mathrm{kg} / \mathrm{wk} /$ haemoglobin for epoetintreated patients and $\geq 0.005 \mu \mathrm{g} / \mathrm{kg} / \mathrm{wk} / \mathrm{g}$ haemoglobin for darbepoetin-treated patients (Johnson 2008). Table 1 presents current definitions of ESA resistance.

An emerging body of evidence indicates more harm than benefit from targeting higher haemoglobin levels with ESA therapy. Patients who needed higher doses of ESA experienced increased mortality at any haemoglobin level, and patients who achieved target haemoglobin levels had better outcomes than those who did not.

Further RCTs are needed urgently to consider the clinical impacts of therapies purported to reduce ESA resistance.

\section{A U THORS' CONCLUSIONS}

\section{Implications for practice}

Based on two small, single-centre studies, there was inadequate evidence to recommend any intervention to ameliorate ESA-hyporesponsiveness.

\section{Implications for research}

Adequately powered multicentre RCTs involving a wide range of CKD patients receiving ESA therapy should be conducted as a priority. In addition to those on haemodialysis, future RCTs should include pre-dialysis CKD patients as well people receiving peritoneal dialysis.

Future studies should focus on true ESA responsiveness rather than a haemoglobin-targeted approach. Importantly, these studies should also include cost-effectiveness and economic analyses.

\section{ACKNOWLEDGEMENTS}

The authors would like to acknowledge Narelle Willis and Ruth Mitchell from the Cochrane Renal Group for their assistance. The authors would also like to thank the referees for their editorial advice during the preparation of this review.

\section{R E F E R E N C E S}

\section{References to studies included in this review}

\section{Attallah 2006 \{published data only\}}

Attallah N, Osman-Malik Y, Adams B, Frinak S, Besarab

A. Effect of intravenous ascorbic acid in hemodialysis patients with erythropoietin-hyporesponsive anemia and hyperferritenemia [abstract]. Journal of the American Society of Nephrology 2005;16:488A.

* Attallah N, Osman-Malik Y, Frinak S, Besarab A. Effect of intravenous ascorbic acid in hemodialysis patients with EPO-hyporesponsive anemia and hyperferritinemia. American Journal of Kidney Diseases 2006;47(4):644-54. MEDLINE: 16564942

Ayli 2004 \{published data only\} Ayli D, Ayli M, Azak A, Yksel C, Kosmaz GP, Atilgan G, et al. The effect of high-flux hemodialysis on renal anemia. Journal of Nephrology 2004;17(5):701-6. MEDLINE: 15593038

Ayli M, Ayli D, Azak A, Yuksel C, Atilgan G, Dede F, et al. The effect of high-flux hemodialysis on dialysis-associated amyloidosis. Renal Failure 2005;27(1):31-4. MEDLINE: 15717632

\section{References to studies excluded from this review}

\section{Abe 2010 \{published data only\}}

Abe M, Okada K, Maruyama T, Maruyama N, Soma $\mathrm{M}$, Matsumoto K. Clinical effectiveness and safety evaluation of long-term pioglitazone treatment for erythropoietin responsiveness and insulin resistance in type 2 diabetic patients on hemodialysis. Expert Opinion on Pharmacotherapy 2010;11(10):1611-20. MEDLINE: 20540652

Acchiardo 1989 \{published data only\} Acchiardo SR, Quinn BP, Burk LB, Moore LW. Are high flux dialysis and erythropoietin treatment in a collision course? . ASAIO Transactions 1989;35(3):308-10. MEDLINE: 2688711

Aliev 1997 \{published data only\}

Aliev MA, Ismagilov RZ, Tsoy GM, Yusumbaeva AS. Influence of Eprex in combination with antihistamine 
drugs on correction of anemia in haemodialysis patients [abstract]. 34th Congress European Renal Association/ European Dialysis and Transplantation Association; Geneva, Switzerland. 1997:236.

Andrulli 2010 \{published data only\} Andrulli S, Di Filippo S, Manzoni C, Stefanelli L, Floridi A, Galli F, et al. Effect of synthetic vitamin E-bonded membrane on responsiveness to erythropoiesis-stimulating agents in hemodialysis patients: a pilot study. Nephron 2010;115(1):c82-9. MEDLINE: 20215781

Ballal 1991 \{published data only\} Ballal SH, Domoto DT, Polack DC, Marciulonis P, Martin $\mathrm{KJ}$. Androgens potentiate the effects of erythropoietin in the treatment of anemia of end-stage renal disease. American Journal of Kidney Diseases 1991;17(1):29-33. MEDLINE: 1986567

Barany 1998 \{published data only\}

Barany P. Treatment of anemia in hemodialysis patients to a normal hemoglobin concentration - results of an open randomized clinical trial of epoetin beta [abstract]. Journal of the American Society of Nephrology 1998;9:243A.

Berns 1992 \{published data only\}

Berns JS, Rudnick MR, Cohen RM. A controlled trial of recombinant human erythropoietin and nandrolone decanoate in the treatment of anemia in patients on chronic hemodialysis. Clinical Nephrology 1992;37(5):264-7. MEDLINE: 1606777

Brockenbrough 2006 \{published data only\} Brockenbrough AT, Dittrich MO, Page ST, Smith T, Stivelman JC, Bremner WJ. Transdermal androgen therapy to augment EPO in the treatment of anemia of chronic renal disease. American Journal of Kidney Diseases 2006;47 (2):251-62. MEDLINE: 16431254

Buchwald 1977 \{published data only\} Buchwald D, Argyres S, Easterling RE, Oelshlegel FJ, Brewer GJ, Schoomaker EB, et al. Effect of nandrolone decanoate on the anemia of chronic hemodialysis patients. Nephron 1977;18(4):232-8. MEDLINE: 323739

\section{Cao 2010 \{published data only\}} Cao W, Liu JH, Zhang H, Zhang L, Zhang LY, Pan MM. Effect of acupoint injection on erythropoietin resistance in patients with chronic renal failure. Zhongguo Zhenjiu [Chinese Acupuncture \& Moxibustion] 2010;30(11):891-5. MEDLINE: 21246842

Caruso 1998 \{published data only\}

Caruso U, Leone L, Cravotto E, Nava D. Effects of L-carnitine on anemia in aged hemodialysis patients treated with recombinant human erythropoietin: A pilot study. Dialysis \& Transplantation 1998;27(8):498-506. [EMBASE: 1998284168]

\section{Cerulli 2000 \{published data only\}}

The effect of hemodiafiltration with on-line endogenous reinfusion (on-line HFR) on anemia: design of a European, open, randomised, multicentre trial. European Collaborative Study. Journal of Nephrology 2000;13(1): 34-42. MEDLINE: 10720212
Chan 2005 \{published data only\}

Chan D, Irish A, Croft KD, Dogra G. Effect of ascorbic acid supplementation on plasma isoprostanes in haemodialysis patients. Nephrology Dialysis Transplantation 2006;21(1): 234-5. MEDLINE: 16204285

Chan D, Irish A, Dogra G. Efficacy and safety of oral compared with intravenous ascorbic acid in improving anaemia in erythropoietin hyporesponsive, iron overloaded, haemodialysis patients - a randomised open-label study [abstract]. Nephrology 2003;8 Suppl 3:A80-1.

Chan D, Irish A, Dogra G. Efficacy and safety of oral versus intravenous ascorbic acid for anaemia in haemodialysis patients. Nephrology 2005;10(4):336-40. MEDLINE: 16109077

\section{Chen 2003 \{published data only\}} Chen WT, Lin YF, Yu FC, Kao WY, Huang WH, Yan HC. Effect of ascorbic acid administration in hemodialysis patients on in vitro oxidative stress parameters: influence of serum ferritin levels. American Journal of Kidney Diseases 2003;42(1):158-66. MEDLINE: 12830468

Cruz 2008 \{published data only\} Cruz DN, De Cal M, Garzotto F, Brendolan A, Nalesso F, Corradi V, et al. Effect of vitamin E-coated dialysis membranes on anemia in patients with chronic kidney disease: an Italian multicenter study. International Journal of Artificial Organs 2008;31(6):545-52. MEDLINE: 18609507

Culleton 2007 \{published data only\}

Culleton BF, Walsh M, Klarenbach SW, Mortis G, Scott-Douglas N, Quinn RR, et al. Effect of frequent nocturnal hemodialysis vs conventional hemodialysis on left ventricular mass and quality of life: a randomized controlled trial. JAMA 2007;298(11):1291-9. MEDLINE: 17878421 Culleton BF, Walsh M, Klarenbach SW, Mortis G, ScottDouglas N, Quinn RR, et al. Nocturnal hemodialysis lowers blood pressure and reduces left ventricular mass: results of a randomized controlled trial [abstract]. Journal of the American Society of Nephrology 2007;18(Abstracts): 67A-8A.

Khangura J, Culleton BF, Manns BJ, Zhang J, Barnieh $\mathrm{L}$, Walsh M, et al. Association between routine and standardized blood pressure measurements and left ventricular hypertrophy among patients on hemodialysis. BMC Nephrology 2010;11:13. MEDLINE: 20576127 Manns BJ, Klarenbach S, Walsh M, Quinn R, Tonelli $\mathrm{M}$, Scott-Douglas N, et al. The impact of nocturnal hemodialysis on quality of life: results of a randomized controlled trial [abstract]. Journal of the American Society of Nephrology 2007;18(Abstracts):298A-9A.

Manns BJ, Walsh MW, Culleton BF, Hemmelgarn B, Tonelli M, Schorr M, et al. Nocturnal hemodialysis does not improve overall measures of quality of life compared to conventional hemodialysis. Kidney International 2009;75 (5):542-9. MEDLINE: 19109588

Schorr M, Manns BJ, Culleton B, Walsh M, Klarenbach S, Tonelli M, et al. The effect of nocturnal and conventional hemodialysis on markers of nutritional status: results from 
a randomized trial. Journal of Renal Nutrition 2011;21(3): 271-6. MEDLINE: 20650654

Walsh M, Manns B, Tonelli M, Quinn R, Culleton B. Description of a randomized controlled trial on the effects of nocturnal hemodialysis on left ventricular hypertrophy compared to conventional hemodialysis [abstract]. Journal of the American Society of Nephrology 2005;16:734A-5A. Walsh M, Manns BJ, Klarenbach S, Quinn R, Tonelli $\mathrm{M}$, Culleton BF. The effects of nocturnal hemodialysis compared to conventional hemodialysis on change in left ventricular mass: rationale and study design of a randomized controlled pilot study. BMC Nephrology 2006; 7:2. MEDLINE: 16504054

Walsh M, Manns BJ, Klarenbach S, Tonelli M, Hemmelgarn $B$, Culleton B. The effects of nocturnal compared with conventional hemodialysis on mineral metabolism: a randomized-controlled trial. Hemodialysis International 2010;14(2):174-81. MEDLINE: 20041960

Deira 2003 \{published data only\}

Deira J, Diego J, Martinez R, Oyarbide A, Gonzalez A, Diaz $\mathrm{H}$, et al. Comparative study of intravenous ascorbic acid versus low-dose desferroxamine in patients on hemodialysis with hyperferritinemia. Journal of Nephrology 2003;16(5): 703-9. MEDLINE: 14733417

Di Iorio 2003 \{published data only\}

Di Iorio BR, Bellizzi V, Minutolo R, De Nicola L, Iodice C, Conte G. Supplemented very low-protein diet in advanced CRF: is it money saving?. Kidney International 2004;65(2): 742. MEDLINE: 14717953

Di Iorio BR, Minutolo R, De Nicola L, Bellizzi V, Catapano F, Iodice C, et al. Supplemented very low protein diet ameliorates responsiveness to erythropoietin in chronic renal failure. Kidney International 2003;64(5):1822-8. MEDLINE: 14531817

ECAP Study 2006 \{published data only\}

Rossert J, Gassmann-Mayer C, Frei D, McClellan W. Prevalence and predictors of epoetin hyporesponsiveness in chronic kidney disease patients. Nephrology Dialysis Transplantation 2007;22(3):794-800. MEDLINE: 17210593

Rossert J, Gassmann-Mayer C, Frei D, McClellan W. Prevalence and risk factors for erythropoetin hyporesponsiveness in chronic kidney disease: analysis of the ECAP study [abstract]. Journal of the American Society of Nephrology 2004;15(Oct):141A.

Rossert J, Levin A, Roger S, Horl W, Gassman-Mayer C, Frei D, et al. Effect of early correction of anemia on the progression of chronic kidney disease: final results ECAP study [abstract]. Journal of the American Society of Nephrology 2004;15(Oct):546A.

* Rossert J, Levin A, Roger SD, Horl WH, Fouqueray B, Gassmann-Mayer C, et al. Effect of early correction of anemia on the progression of CKD. American Journal of Kidney Diseases 2006;47(5):738-50. MEDLINE: 16632012

Rossert J, Roger S, Levin A, Horl W, McClellan W. Effect on early correction of anemia on the progression of chronic kidney disease (ECAP) [abstract]. Journal of the American Society of Nephrology 2003;14(Nov):811A.

Eiselt 2000 \{published data only\}

Eiselt J, Racek J, Opatrny K. The effect of hemodialysis and acetate-free biofiltration on anemia. International Journal of Artificial Organs 2000;23(3):173-80. MEDLINE: 10795662

\section{Garcia Cortes 1999 \{published data only\}} Garcia Cortes MJ, Sanchez Pearles MC, Perez del Barrio MP, Borrego Utiel FJ, Liebana A, Borrego Hinojosa J, et al. Effects of biocompatible membranes on uremic anemia in hemodialysis patients [abstract]. Nephrology Dialysis Transplantation 1999;14(9):A260.

Garcia Cortes MJ, Sanchez Perales MC, Liebana A, Gil JM, Borrego FJ, Borrego J, et al. Beneficial effect of AN69 membranes on anemia in hemodialyzed patients. Nefrologia 2001;21(4):370-5. MEDLINE: 11816513

Garrote 2009 \{published data only\}

Garrote N, Guinsburg M, Garcia L, Boubee S, Moretto $\mathrm{H}$, Canale R, et al. Vitamin C improves HB levels and reduce $\mathrm{EPO}$ resistance in hemodialysis (HD) patients with functional iron deficiency (FID). A randomized, open label, controlled multicentric trial [abstract SA778]. World Congress of Nephrology; 2009 May 22-26; Milan (Italy). 2009.

\section{Gastaldello 1995 \{published data only\}}

Gastaldello K, Vereerstraeten A, Nzame-Nze T, Vanherweghem JL, Tielemans C. Resistance to erythropoietin in iron-overloaded haemodialysis patients can be overcome by ascorbic acid administration. Nephrology Dialysis Transplantation 1995;10(Suppl 6):44-7. MEDLINE: 8524494

\section{Gaughan 1997 \{published data only\}}

Gaughan WJ, Liss KA, Dunn SR, Mangold AM, Buhsmer JP, Michael B, et al. A 6-month study of lowdose recombinant human erythropoietin alone and in combination with androgens for the treatment of anemia in chronic hemodialysis patients. American Journal of Kidney Diseases 1997;30(4):495-500. MEDLINE: 9328363 Liss KA, Gaughan WJ, Dunn SR, Michael B, Goldman JM, Armenti VT, et al. A six month study of lowdose recombinant human erythropoietin alone and in combination with androgen for the treatment of anemia in chronic hemodialysis patients [abstract]. Journal of the American Society of Nephrology 1996;7(9):1490.

Giancaspro 2000 \{published data only\} Giancaspro V, Nuzziello M, Pallotta G, Sacchetti A, Petrarulo F. Intravenous ascorbic acid in hemodialysis patients with functional iron deficiency: a clinical trial. Journal of Nephrology 2000;13(6):444-9. MEDLINE: 11132761

\section{Hakemi 2005 \{published data only\}}

Hakemi MS, Ganji MR, Najafi I, Shekarchi M. Intravenous ascorbic acid in comparison to intravenous iron in erythropoietin resistant anemia with iron overload in hemodialysis patients [abstract]. Nephrology 2005;10 (Suppl):A314. 
Hsu 2004 \{published data only\}

Hsu PY, Lin CL, Yu CC, Chien CC, Hsiau TG, Sun TH, et al. Ultrapure dialysate improves iron utilization and erythropoietin response in chronic hemodialysis patients - a prospective cross-over study. Journal of Nephrology 2004;17 (5):693-700. MEDLINE: 15593037

Hung 2005 \{published data only\}

Hung SC, Tung TY, Yang CS, Tarng DC. High-calorie supplementation increases serum leptin levels and improves response to $\mathrm{rHuEPO}$ in long-term hemodialysis patients. American Journal of Kidney Diseases 2005;45(6):1073-83. MEDLINE: 15957137

Imada 2001 \{published data only\}

Imada A, Yoshimoto S, Ohno T, Takahashi K, Imada T, Iida N. Effect of Vitamin C on recombinant human erythropoietin refractory anemia in patients with chronic hemodialysis [abstract]. Journal of the American Society of Nephrology 2001;12(Program \& Abstracts):332A.

ISRCTN96315193 \{published data only\}

Comparison of the effect of erythropoietin, L-carnitine and erythropoietin plus L-carnitine in correction of anemia in chronic hemodialysis patients. http://www.controlledtrials.com/ISRCTN96315193/ISRCTN96315193 (accessed 11th March 2013).

Jacobs 2006 \{published data only\}

Jacobs C. Intravenous vitamin C can improve anemia in erythropoietin-hyporesponsive hemodialysis patients. Nature Clinical Practice Nephrology 2006;2(10):552-3. MEDLINE: 17003830

Janssen 1995 \{published data only\} Janssen MJ, van der Kuy A, ter Wee PM, van Boven WP. Calcium acetate versus calcium carbonate and erythropoietin dosages in haemodialysis patients. Nephrology Dialysis Transplantation 1995;10(12):2321-4. MEDLINE: 8808233

Kato 2000 \{published data only\}

Kato A, Takita T, Furuhashi M, Takahashi T, Maruyama Y, Hishida A. No effect of losartan on response to erythropoietin therapy in patients undergoing hemodialysis. Nephron 2000;86(4):538-9. MEDLINE: 11124620

Keven 2003 \{published data only\}

Deicher R, Horl WH. Vitamin C for hyporesponsiveness to EPO: a cure for all?. American Journal of Kidney Diseases 2003;42(4):848-9. MEDLINE: 14520639

Keven K, Kutlay S, Nergizoglu G, Duman N, Erturk S. The effect of intravenous vitamin $\mathrm{C}$ on erythropoietin response in haemodialysis patients [abstract]. Nephrology Dialysis Transplantation 2002;17(Suppl 1):229.

Keven K, Kutlay S, Nergizoglu G, Erturk S. Randomized, crossover study of the effect of vitamin $\mathrm{C}$ on EPO response in hemodialysis patients. American Journal of Kidney Diseases 2003;41(6):1233-9. MEDLINE: 12776276 Keven K, Kutlay S, Nergizoglu G, Erturk S. The effect of Vitamin $\mathrm{C}$ on erythropoietin response in hemodialysis patients [abstract]. Journal of the American Society of Nephrology 2001;12(Program \& Abstracts):357A-8A.
Klarenbach 2002 \{published data only\}

Klarenbach S, Heidenheim AP, Leitch R, Lindsay RM, Daily/Nocturnal Dialysis Study Group. Reduced requirement for erythropoietin with quotidian hemodialysis therapy. ASAIO Journal 2002;48(1):57-61. MEDLINE: 11814098

Kletzmayr 1999 \{published data only\}

Kletzmayr J, Mayer G, Legenstein E, Heinz-Peer G, Leitha T, Horl WH, et al. Anemia and carnitine supplementation in hemodialyzed patients. Kidney International - Supplement 1999;55(Suppl 69):S93-S106. MEDLINE: 10084293

Koronis 2000 \{published data only\}

Koronis C, Makris F, Stavroulaki E, Lambropoulou A, Orthopoulos V. Combination of low-dose recombinant human erythropoietin with androgens for the treatment of anaemia in hemodialysis patients [abstract]. 37th Congress. European Renal Association. European Dialysis and Transplantation Association. European Kidney Research Organisation; Nice (France). 2000:235.

Labonia 1995 \{published data only\}

Labonia WD. L-carnitine effects on anemia in hemodialyzed patients treated with erythropoietin. American Journal of Kidney Diseases 1995;26(5):757-64. MEDLINE: 7485128

Lee 2001 \{published data only\}

Lee M, Ahn S, Song J. Effects of adjuvant androgen on anemia and nutritional parameters in chronic hemodialysis patients using low-dose recombinant human erythropoietin [abstract]. Journal of the American Society of Nephrology 2001;12(Program \& Abstracts):358A-9A.

Locatelli 1999 \{published data only\}

Locatelli F, Andrulli S, Del Vecchio L. Anemia of hemodialysis patients: evaluation of the effect of BKF polymethylmethacrylate membrane. Contributions to Nephrology 1999;125:173-81. MEDLINE: 9895439

Locatelli 2000 \{published data only\} Locatelli F, Andrulli S, Pecchini F, Pedrini L, Agliata S, Lucchi L, et al. Effect of high-flux dialysis on the anaemia of haemodialysis patients. Nephrology Dialysis Transplantation 2000;15(9):1399-409. MEDLINE: 10978398

Malegos 2000 \{published data only\}

Malegos I, Kaloheretis P, Drouzas A, Papadakis I.

Does haemodialysis membrane's biocompatibility affect recombinant human erythropoietin ( $\mathrm{rHuEPO}$ ) effect on the anemia of hemodialyzed patients? [abstract]. Nephrology Dialysis Transplantation 2000;15(9):A156.

Miyahara 1990 \{published data only\}

Miyahara S, Motomori T, Miyazaki F, Noda S, Eto K, Nakamura Y, et al. Clinical studies of mepitiostane for treatment of anemia associated with chronic renal failure. Kiso to Rinsho (The Clinical Report) 1990;24(5):2963-8.

Mydlík 2003 \{published data only\} Mydlík M, Derzsiová K, Boldizsár J, Hríbiková $\mathrm{M}$, Petrovicová J. Oral use of iron with vitamin $\mathrm{C}$ in hemodialyzed patients. Journal of Renal Nutrition 2003;13 (1):47-51. MEDLINE: 12563623 
Nakamoto 2008 \{published data only\}

Nakamoto H, Mimura T, Honda N. Orally administrated Juzen-taiho-to/TJ-48 ameliorates erythropoietin ( $\mathrm{rHuEPO}$ )-resistant anemia in patients on hemodialysis. Hemodialysis International 2008;12(Suppl 2):S9-S14. MEDLINE: 18837771

Navarro 2002 \{published data only\} Navarro JF, Mora C, Macia M, Chahin J, Gallego E, Mendez ML, et al. Effects of androgen therapy on hematologic and nutritional parameters in elderly peritoneal dialysis patients [abstract]. International Urology \& Nephrology 2001;33(4): 715-6.

Navarro JF, Mora C, Macia ML, Gallego E, Chahin J, Mendez ML, et al. Prospective comparison between rHuEPO and androgens in CAPD patients: impact on hematologic and nutritional parameters [abstract]. Journal of the American Society of Nephrology 2001;12(Program \& Abstracts):436A.

* Navarro JF, Mora C, Macía M, García J. Randomized prospective comparison between erythropoietin and androgens in CAPD patients. Kidney International 2002;61 (4):1537-44. MEDLINE: 11918762

Odabas 2003 \{published data only\} Odabas AR, Cetinkaya R, Selcuk Y, Keles S, Bilen H. The effect of high dose losartan on erythropoietin resistance in patients undergoing haemodialysis. Panminerva medica 2003;45(1):59-62. MEDLINE: 12682621

Ono 1992 \{published data only\}

Ono K, Hisasue Y. Is folate supplementation necessary in hemodialysis patients on erythropoietin therapy. Clinical Nephrology 1992;38(5):290-2. MEDLINE: 1451343

Onoyama 1989 \{published data only\}

Onoyama K, Sanai T, Motomura K, Fujishima M. Worsening of anemia by angiotensin converting enzyme inhibitors and its prevention by antiestrogenic steroid in chronic hemodialysis patients. Journal of Cardiovascular Pharmacology 1989;13(Suppl 3):S27-S30. MEDLINE: 2474097

Opatrnì 1998 \{published data only\}

Opatrný K Jr, Krouzecký A, Wirth J, Vít L, Eiselt J. The effects of a polyacrylonitrile membrane and a membrane made of regenerated cellulose on the plasma concentrations of erythropoietin during hemodialysis. Artificial Organs 1998;22(10):816-20. MEDLINE: 9790077

Panichi 2011 \{published data only\}

Panichi V, Barattini M, Angelini D, Petrone I, Ferrandello FP, Grazi G, et al. A vitamin E-coated polysulfone membrane reduces inflammatory markers and EPO requirement in haemodialysis patients [abstract SA413]. World Congress of Nephrology; 2009 May 22-26; Milan (Italy). 2009.

Panichi V, Rosati A, Paoletti S, Ferrandello P, Migliori M, Beati S, et al. A vitamin E-coated polysulfone membrane reduces serum levels of inflammatory markers and resistance to erythropoietin-stimulating agents in hemodialysis patients: results of a randomized cross-over multicenter trial. Blood Purification 2011;32(1):7-14. MEDLINE: 21242686

Rao 2003 \{published data only\}

Rao M, Muirhead N, Klarenbach S, Moist L, Lindsay RM. Management of anemia with quotidian hemodialysis. American Journal of Kidney Diseases 2003;42(1 Suppl): 18-23. MEDLINE: 12830439

Richardson 2003 \{published data only\}

Richardson D, Lindley E, Bartlett C, Will EJ.

Biocompatibility and erythropoiesis: - a randomised controlled, single center study of modified cellulose and polysulfone dialysers in a large hemodialysis cohort $(\mathrm{n}=$ 177) [abstract]. Journal of the American Society of Nephrology 2001;12(Program \& Abstracts):240A

Richardson D, Lindley EJ, Bartlett C, Will EJ. A randomized, controlled study of the consequences of hemodialysis membrane composition on erythropoietic response. American Journal of Kidney Diseases 2003;42(3): 551-60. MEDLINE: 12955684

Saxena 1997 \{published data only\}

Saxena S, Dash SC, Tiwari SC, Agarwal SK, Jain PK, Aslam $\mathrm{J}$. Effect of nandrolone deconoate on response to low dose erythropoietin (EPO) in anemia of end stage renal disease (ESRD) patients on maintenance hemodialysis (MHD) [abstract]. Nephrology 1997;3(Suppl 1):S310.

Sezer 2002 \{published data only\}

Sezer S, Ozdemir FN, Yakupoglu U, Arat Z, Turan M, Haberal M. Intravenous ascorbic acid administration for erythropoietin-hyporesponsive anemia in iron loaded hemodialysis patients. Artificial Organs 2002;26(4):366-70. MEDLINE: 11952508

Shahrbanoo 2008 \{published data only\} Shahrbanoo K, Taziki O. Effect of intravenous ascorbic acid in hemodialysis patients with anemia and hyperferritinemia. Saudi Journal of Kidney Diseases \& Transplantation 2008;19 (6):933-6. MEDLINE: 18974579

Sheashaa 2005 \{published data only\}

Sheashaa H, Abdel-Razek W, El Husseini A, Selim A, Hassan N, Abbas T, et al. Use of nandrolone decanoate as an adjuvant for erythropoietin dose reduction in treating anemia in patients on hemodialysis. Nephron 2005;99(4): c102-6. MEDLINE: 15703460

Sorge-Haedicke 2001 \{published data only\}

Sorge-Haedicke B, Goncalves-Marques M, Loew L, Samizadeh A. Routine intravenous 1-carnitinesupplementation does not reduce erythropoietin (RH$\mathrm{EPO}$ )- requirement in chronic hemodialysis (CHD) patients (P) with renal anemia (RA). Nephrology Dialysis Transplantation 2001;16(6):A135.

Taji 2004 \{published data only\}

Taji Y, Morimoto T, Okada K, Fukuhara S, Fukui T, Kuwahara T. Effects of intravenous ascorbic acid on erythropoiesis and quality of life in unselected hemodialysis patients. Journal of Nephrology 2004;17(4):537-43. MEDLINE: 15372416 
Tarng 1998 \{published data only\}

Tarng DC, Huang TP. A parallel, comparative study of intravenous iron versus intravenous ascorbic acid for erythropoietin-hyporesponsive anaemia in haemodialysis patients with iron overload. Nephrology Dialysis Transplantation 1998;13(11):2867-72. MEDLINE: 9829492

Tarng 1999 \{published data only\}

Tarng DC, Wei YH, Huang TP, Kuo BI, Yang WC. Intravenous ascorbic acid as an adjuvant therapy for recombinant erythropoietin in hemodialysis patients with hyperferritinemia. Kidney International 1999;55(6): 2477-86. MEDLINE: 10354297

Tarng 2004 \{published data only\}

Tarng DC, Hung SC, Huang TP. Effect of intravenous ascorbic acid medication on serum levels of soluble transferrin receptor in hemodialysis patients. Journal of the American Society of Nephrology 2004;15(9):2486-93. MEDLINE: 15339999

Ursea 1995 \{published data only\}

Ursea N, Capsa D. Faster improvement of the anemia in chronic hemodialysed patients with combined treatment with erythropoetin and essential amino acids ketoanalogues [abstract]. Nephrology Dialysis Transplantation 1995;10(6): 1051.

Usberti 2002a \{published data only\}

Usberti M, Gerardi G, Bufano G, Tira P, Micheli A, Albertini A, et al. Effects of erythropoietin and vitamin E-modified membrane on plasma oxidative stress markers and anemia of hemodialyzed patients. American Journal of Kidney Diseases 2002;40(3):590-9. MEDLINE: 12200812

Usberti 2002b \{published data only\}

Usberti M, Gerardi G, Micheli A, Tira P, Bufano G, Gaggia P, et al. Effects of a vitamin E-bonded membrane and of glutathione on anemia and erythropoietin requirements in hemodialysis patients. Journal of Nephrology 2002;15(5): 558-64. MEDLINE: 12455724

Vaslaki 2006 \{published data only\}

Vaslaki L, Berta K, Ladanyi E, Pethoe F, Karatson A, Misz M, et al. Less need for erythropoietin in on-line haemodiafiltration compared to haemodialysis [abstract]. Nephrology Dialysis Transplantation 2005;20(Suppl 5):v336. Vaslaki L, Major L, Berta K, Karatson A, Misz M, Pethoe $\mathrm{F}$, et al. On-line haemodiafiltration versus haemodialysis: stable haematocrit with less erythropoietin and improvement of other relevant blood parameters. Blood Purification 2006; 24(2):163-73. MEDLINE: 16352871

Wang 2000 \{published data only\}

Wang M-C, Huang J-J, Liao L-H, Ruaan M-K, Sung J-M, Lan R-R. Effect of high-dose folic acid on hemodialysis patients with poor erythropoietin response. Dialysis \& Transplantation 2000;29(11):710-7. [EMBASE: 2000401292]

Yang 2006 \{published data only\}

Yang CC, Hsu SP, Wu MS, Hsu SM, Chien CT. Effects of vitamin $\mathrm{C}$ infusion and vitamin $\mathrm{E}$-coated membrane on hemodialysis-induced oxidative stress. Kidney International 2006;69(4):706-14. MEDLINE: 16395251

\section{References to ongoing studies}

\section{Johnson 2008 \{published data only\}}

Johnson DW, Hawley CM, Rosser B, Beller E, Thompson C, Fassett RG, et al. Oxpentifylline versus placebo in the treatment of erythropoietin-resistant anaemia: a randomized controlled trial. BMC Nephrology 2008;9:8. MEDLINE: 18671885

\section{NCT01526798 \{published data only\}} Improvement of EPO-resistance in hemodialysis patients with chronic inflammation by high cut-off hemodialysis (CIEPO-PILOT). http://www.clinicaltrials.gov/ct2/results? term=NCT01526798 (accessed 18th March 2013).

\section{Additional references}

\section{Badve 2011}

Badve SV, Hawley CM, Johnson DW. Is the problem with the vehicle or the destination? Does high-dose ESA or high haemoglobin contribute to poor outcomes in CKD?. Nephrology 2011;16(2):144-53. MEDLINE: 21272125

\section{Benz 1999}

Benz RL, Pressman MR, Hovick ET, Peterson DD. A preliminary study of the effects of correction of anemia with recombinant human erythropoietin therapy on sleep, sleep disorders, and daytime sleepiness in hemodialysis patients (The SLEEPO study). American Journal of Kidney Diseases 1999;34(6):1089-95. MEDLINE: 10585319

\section{Besarab 1998}

Besarab A, Bolton WK, Browne JK, Egrie JC, Nissenson AR, Okamoto DM, et al. The effects of normal as compared with low hematocrit values in patients with cardiac disease who are receiving hemodialysis and epoetin. New England Journal of Medicine 1998;339(9):584-90. MEDLINE: 9718377

\section{Brookhart 2010}

Brookhart MA, Schneeweiss S, Avorn J, Bradbury BD, Liu J, Winkelmayer WC. Comparative mortality risk of anemia management practices in incident hemodialysis patients. JAMA 2010;303(9):857-64. MEDLINE: 20197532

\section{Eschbach 1989}

Eschbach JW, Kelly MR, Haley NR, Abels RI, Adamson JW. Treatment of the anemia of progressive renal failure with recombinant human erythropoietin. New England Journal of Medicine 1989;321(3):158-63. MEDLINE: 2747747

\section{Gandra 2010}

Gandra SR, Finkelstein FO, Bennett AV, Lewis EF, Brazg T, Martin ML. Impact of erythropoiesis-stimulating agents on energy and physical function in nondialysis CKD patients with anemia: a systematic review. American Journal of Kidney Diseases 2010;55(3):519-34. MEDLINE: 20031287 
Higgins 2003

Higgins JP, Thompson SG, Deeks JJ, Altman DG.

Measuring inconsistency in meta-analyses. BMJ 2003;327

(7414):557-60. MEDLINE: 12958120

\section{Higgins 2011}

Higgins JP, Green S (editors). Cochrane Handbook for Systematic Reviews of Interventions Version 5.1.0 [updated March 2011]. The Cochrane Collaboration, 2011. Available from www.cochrane-handbook.org.

\section{Kausz 2005}

Kausz AT, Solid C, Pereira BJ, Collins AJ, St Peter W. Intractable anemia among hemodialysis patients: a sign of suboptimal management or a marker of disease?. American Journal of Kidney Diseases 2005;45(1):136-47. MEDLINE: 15696453

KDOQI 2001

NKF KDOQI Clinical Practice Guidelines for Anemia of Chronic Kidney Disease: update 2000. American Journal of Kidney Diseases 2001;37(1 Suppl 1):S182-238. MEDLINE: 11229970

\section{KDOQI 2006}

KDOQI. National Kidney Foundation. KDOQI Clinical Practice Guidelines and Clinical Practice Recommendations for Anemia in Chronic Kidney Disease. American Journal of Kidney Diseases 2006;47(5 Suppl 3):S11-145. MEDLINE: 16678659

\section{Kilpatrick 2008}

Kilpatrick RD, Critchlow CW, Fishbane S, Besarab A, Stehman-Breen C, Krishnan M, et al. Greater epoetin alfa responsiveness is associated with improved survival in hemodialysis patients. Clinical Journal of The American Society of Nephrology: CJASN 2008;3(4):1077-83. MEDLINE: 18417744

\section{Locatelli 2004}

Locatelli F, Aljama P, Barany P, Canaud B, Carrera F, Eckardt $\mathrm{KU}$, et al. Revised European best practice guidelines for the management of anaemia in patients with chronic renal failure. Nephrology Dialysis Transplantation 2004;19(Suppl 2):ii1-47. MEDLINE: 15206425

\section{Macdougall 2002}

Macdougall IC, Cooper AC. Erythropoietin resistance: the role of inflammation and pro-inflammatory cytokines. Nephrology Dialysis Transplantation 2002;17(Suppl 11): 39-43. MEDLINE: 12386257

\section{Messana 2009}

Messana JM, Chuang CC, Turenne M, Wheeler J, Turner J, Sleeman K, et al. Association of quarterly average achieved hematocrit with mortality in dialysis patients: a time-dependent comorbidity-adjusted model. American Journal of Kidney Diseases 2009;53(3):503-12. [PUBMED: 19185402]

\section{Palmer 2010}

Palmer SC, Navaneethan SD, Craig JC, Johnson DW, Tonelli M, Garg AX, et al. Meta-analysis: Erythropoiesisstimulating agents in patients with chronic kidney disease. Annals of Internal Medicine 2010;153(1):23-33.

MEDLINE: 20439566

\section{Pfeffer 2009}

Pfeffer MA, Burdmann EA, Chen CY, Cooper ME, de Zeeuw D, Eckardt KU, et al. A trial of darbepoetin alfa in type 2 diabetes and chronic kidney disease. New England Journal of Medicine 2009;361(21):2019-32. MEDLINE: 19880844

Phrommintikul 2007

Phrommintikul A, Haas SJ, Elsik M, Krum H. Mortality and target haemoglobin concentrations in anaemic patients with chronic kidney disease treated with erythropoietin: a meta-analysis. Lancet 2007;369(9559):381-8. MEDLINE: 17276778

Regidor 2006

Regidor DL, Kopple JD, Kovesdy CP, Kilpatrick RD, McAllister CJ, Aronovitz J, et al. Associations between changes in hemoglobin and administered erythropoiesisstimulating agent and survival in hemodialysis patients. Journal of the American Society of Nephrology 2006;17(4): 1181-91. MEDLINE: 16565261

Singh 2006

Singh AK, Szczech L, Tang KL, Barnhart H, Sapp S, Wolfson $\mathrm{M}$, et al. Correction of anemia with epoetin alfa in chronic kidney disease. New England Journal of Medicine 2006;355(20):2085-98. MEDLINE: 17108343

Solomon 2010

Solomon SD, Uno H, Lewis EF, Eckardt KU, Lin J, Burdmann EA, et al. Erythropoietic response and outcomes in kidney disease and type 2 diabetes. New England Journal of Medicine 2010;363(12):1146-55. MEDLINE: 20843249

Szczech 2008

Szczech LA, Barnhart HX, Inrig JK, Reddan DN, Sapp S, Califf RM, et al. Secondary analysis of the CHOIR trial epoetin-alpha dose and achieved hemoglobin outcomes. Kidney International 2008;74(6):791-8. [PUBMED: 18596733]

Valderrabano 1996

Valderrabano F. Erythropoietin in chronic renal failure. Kidney International 1996;50(4):1373-91. MEDLINE: 8887302

Zhang 2004

Zhang Y, Thamer M, Stefanik K, Kaufman J, Cotter DJ. Epoetin requirements predict mortality in hemodialysis patients. American Journal of Kidney Diseases 2004;44(5): 866-76. MEDLINE: 15492953

Zhang 2009

Zhang Y, Thamer M, Cotter D, Kaufman J, Hernan MA. Estimated effect of epoetin dosage on survival among elderly hemodialysis patients in the United States. Clinical Journal of The American Society of Nephrology: CJASN 2009;4(3): 638-44. MEDLINE: 19261818

References to other published versions of this review 
Badve 2010

Badve SV, Beller E, Cass A, Francis DP, Hawley C,

Macdougall IC, et al. Interventions for erythropoietinresistant anaemia in dialysis patients. Cochrane Database of Systematic Reviews 2010, Issue 1. [DOI: 10.1002/ 14651858.CD006861.pub2]

* Indicates the major publication for the study 


\section{CHARACTERISTICS OFSTUDIES}

\section{Characteristics of included studies [ordered by study ID]}

\section{Attallah 2006}

\begin{tabular}{|c|c|}
\hline Methods & $\begin{array}{l}\text { - Study design: RCT } \\
\text { - Time frame: NS } \\
\text { - Follow-up period: } 6 \text { months }\end{array}$ \\
\hline Participants & $\begin{array}{l}\text { - Country: USA } \\
\text { - Setting: large inner-city HD centre } \\
\text { - Inclusion criteria: ESKD patients receiving HD therapy for at least } 6 \text { months; } \\
\text { administered IV EPO } \geq 6 \text { months at dose } \geq 450 \mathrm{U} / \mathrm{kg} / \mathrm{wk} ; 3 \text { month average Hb level } \\
\leq 11 \mathrm{~g} / \mathrm{dL} \text {; ferritin level }>500 \mathrm{ng} / \mathrm{mL} \text {; TSAT } \leq 50 \% \text { and administered maintenance } \\
\text { IV iron } \\
\text { - Number (treatment/control): } 20 / 22 \\
\text { - Age }(\mathrm{mean} \pm \mathrm{SD}) \text { years: treatment group }(50.6 \pm 4.7) \text {; control group }(49.0 \pm 5.9) \\
\text { - Sex }(\mathrm{M} / \mathrm{F}) \text { : treatment group }(9 / 11) \text {; control group }(10 / 12) \\
\text { - Exclusion criteria: bone marrow malignancy; myelodysplastic syndrome; chronic } \\
\text { infection; haemochromatosis; haemoglobinopathies; significant bleeding }(\text { decrease in } \\
\mathrm{Hb}>2 \mathrm{~g} / \mathrm{L}) \text { during the past } 3 \text { months; mean corpuscular volume }>100 \mathrm{fL} \text {; CRP }>20 \\
\mathrm{mg} / \mathrm{dL} ; \mathrm{Bio}-\mathrm{PTH}>500 \mathrm{pg} / \mathrm{mL} \text { (ng/L); aluminium level }>20 \mu \mathrm{Lg} / \mathrm{L}\end{array}$ \\
\hline
\end{tabular}

\begin{tabular}{l} 
Interventions $\begin{array}{c}\text { Treatment group } \\
\bullet \text { Vitamin C } \\
\circ \text { Dose: } 300 \mathrm{mg} \mathrm{IV} \text { on each dialysis session } \\
\text { Control group } \\
\bullet \text { No treatment }\end{array}$ \\
\hline
\end{tabular}

\begin{tabular}{|l|l|}
\hline Outcomes & - Hb level \\
& - EPO dose \\
& - Iron studies \\
& - CRP \\
& - Blood transfusion \\
& - Hospitalisation \\
\hline
\end{tabular}

Notes

- Patients were to be withdrawn from the study if they developed bone marrow malignancy, myelodysplastic syndrome, haemochromatosis, or blood loss of $\geq 500 \mathrm{~mL}$ during the 6 month study period

- Patients on peritoneal dialysis were excluded from the study.

- One patient from the control arm was excluded because of significant upper gastrointestinal bleeding 


\section{Attallah 2006 (Continued)}

\begin{tabular}{|c|c|c|}
\hline Allocation concealment (selection bias) & Unclear risk & $\begin{array}{l}\text { Stated "concealed randomisation was per- } \\
\text { formed using } 1: 1 \text { allocation ratio with } \\
\text { blocks of } 4 \text { ". No further information pro- } \\
\text { vided }\end{array}$ \\
\hline $\begin{array}{l}\text { Blinding (performance bias and detection } \\
\text { bias) } \\
\text { Participants }\end{array}$ & High risk & Open-label \\
\hline $\begin{array}{l}\text { Blinding (performance bias and detection } \\
\text { bias) } \\
\text { Investigators }\end{array}$ & High risk & Open-label \\
\hline $\begin{array}{l}\text { Blinding (performance bias and detection } \\
\text { bias) } \\
\text { Outcome assessors }\end{array}$ & Unclear risk & Not described \\
\hline $\begin{array}{l}\text { Incomplete outcome data (attrition bias) } \\
\text { All outcomes }\end{array}$ & Low risk & $\begin{array}{l}\text { All patients were followed up or accounted } \\
\text { for at } 6 \text { months }\end{array}$ \\
\hline Selective reporting (reporting bias) & Unclear risk & $\begin{array}{l}\mathrm{Hb} \text { changes in individual patient data are } \\
\text { presented in figures only. It was unclear how } \\
\text { many patients in each arm achieved target } \\
\mathrm{Hb}\end{array}$ \\
\hline Other bias & High risk & Single-centre study \\
\hline
\end{tabular}

\section{Ayli 2004}

Methods
- Study design: RCT

- Time frame: NS

- Follow-up period: 6 months
Participants
Participants 


\begin{tabular}{|c|c|c|}
\hline Outcomes & \multicolumn{2}{|c|}{$\begin{array}{l}\text { - Hb level } \\
\text { - HCT level } \\
\text { - EPO dose } \\
\text { - Iron studies } \\
\text { - CRP } \\
\text { - Vitamin } \mathrm{B}_{12} \text { and folic acid levels } \\
\text { - Dialysis adequacy tests (urea reduction ratio and } \mathrm{Kt} / \mathrm{V} \text { urea) } \\
\text { - Beta } 2 \text { microglobulin }\end{array}$} \\
\hline Notes & \multicolumn{2}{|c|}{ - Patients on peritoneal dialysis were excluded from the study } \\
\hline \multicolumn{3}{|l|}{ Risk of bias } \\
\hline Bias & Authors' judgement & Support for judgement \\
\hline $\begin{array}{l}\text { Random sequence generation (selection } \\
\text { bias) }\end{array}$ & Unclear risk & Not described \\
\hline Allocation concealment (selection bias) & Unclear risk & Not described \\
\hline $\begin{array}{l}\text { Blinding (performance bias and detection } \\
\text { bias) } \\
\text { Participants }\end{array}$ & Unclear risk & Not described \\
\hline $\begin{array}{l}\text { Blinding (performance bias and detection } \\
\text { bias) } \\
\text { Investigators }\end{array}$ & Unclear risk & Not described \\
\hline $\begin{array}{l}\text { Blinding (performance bias and detection } \\
\text { bias) } \\
\text { Outcome assessors }\end{array}$ & Unclear risk & Not described \\
\hline $\begin{array}{l}\text { Incomplete outcome data (attrition bias) } \\
\text { All outcomes }\end{array}$ & Low risk & $\begin{array}{l}\text { All patients were followed up or accounted } \\
\text { for at } 6 \text { months }\end{array}$ \\
\hline Selective reporting (reporting bias) & Unclear risk & $\begin{array}{l}\text { Proportion of participants in each arm } \\
\text { achieving target haemoglobin is not de- } \\
\text { scribed. Data on mean EPO dose presented } \\
\text { in figure only }\end{array}$ \\
\hline Other bias & High risk & $\begin{array}{l}\text { Single-centre study, patients on peritoneal } \\
\text { dialysis were excluded }\end{array}$ \\
\hline
\end{tabular}

ACEi - angiotensin-converting enzyme inhibitor; ARB - angiotensin-II receptor blocker; CRP - C-reactive protein; DPO - darbepoetin; EPO - erythropoietin; ESKD - end-stage kidney disease; GFR - glomerular filtration rate; Hb - haemoglobin; HCT - haematocrit; 
HD - haemodialysis; IV - intravenous; NS - not stated; PTH - parathyroid hormone; RCT - randomised controlled trial; SC subcutaneous; TSAT - transferin saturation

Characteristics of excluded studies [ordered by study ID]

\begin{tabular}{|c|c|}
\hline Study & Reason for exclusion \\
\hline Abe 2010 & Study participants did not have ESA resistance. \\
\hline Acchiardo 1989 & Study participants did not have ESA resistance. \\
\hline Aliev 1997 & Study participants did not have ESA resistance. \\
\hline Andrulli 2010 & Study participants did not have ESA resistance. \\
\hline Ballal 1991 & Study participants did not have ESA resistance. \\
\hline Barany 1998 & Study participants did not have ESA resistance. \\
\hline Berns 1992 & Study participants did not have ESA resistance. \\
\hline Brockenbrough 2006 & Study participants did not have ESA resistance. \\
\hline Buchwald 1977 & ESA was not used. \\
\hline Cao 2010 & Study participants did not have ESA resistance. \\
\hline Caruso 1998 & Study participants did not have ESA resistance. \\
\hline Cerulli 2000 & Study participants did not have ESA resistance. \\
\hline Chan 2005 & Study participants did not have ESA resistance. \\
\hline Chen 2003 & Study participants did not have ESA resistance. \\
\hline Cruz 2008 & Not RCT \\
\hline Culleton 2007 & Study participants did not have ESA resistance. \\
\hline Deira 2003 & Study participants did not have ESA resistance. \\
\hline Di Iorio 2003 & Study participants did not have ESA resistance. \\
\hline ECAP Study 2006 & Ineligible patient population \\
\hline Eiselt 2000 & Study participants did not have ESA resistance. \\
\hline
\end{tabular}


(Continued)

\begin{tabular}{|c|c|}
\hline Garcia Cortes 1999 & Study participants did not have ESA resistance. \\
\hline Garrote 2009 & Ineligible patient population (this study included iron deficient patients who lacked true ESA resistance) \\
\hline Gastaldello 1995 & Not RCT \\
\hline Gaughan 1997 & Study participants did not have ESA resistance. \\
\hline Giancaspro 2000 & Ineligible patient population (this study included iron deficient patients who lacked true ESA resistance) \\
\hline Hakemi 2005 & Study participants did not have ESA resistance. \\
\hline Hsu 2004 & Study participants did not have ESA resistance. \\
\hline Hung 2005 & Study participants did not have ESA resistance. \\
\hline Imada 2001 & Study participants did not have ESA resistance. \\
\hline ISRCTN96315193 & Study participants did not have ESA resistance. \\
\hline Jacobs 2006 & Not RCT \\
\hline Janssen 1995 & Study participants did not have ESA resistance. \\
\hline Kato 2000 & Study participants did not have ESA resistance. \\
\hline Keven 2003 & Study participants did not have ESA resistance. \\
\hline Klarenbach 2002 & Not RCT \\
\hline Kletzmayr 1999 & Study participants did not have ESA resistance. \\
\hline Koronis 2000 & Study participants did not have ESA resistance. \\
\hline Labonia 1995 & Study participants did not have ESA resistance. \\
\hline Lee 2001 & Study participants did not have ESA resistance. \\
\hline Locatelli 1999 & Study participants did not have ESA resistance. \\
\hline Locatelli 2000 & Study participants did not have ESA resistance. \\
\hline Malegos 2000 & Study participants did not have ESA resistance. \\
\hline Miyahara 1990 & Study participants did not have ESA resistance. \\
\hline Mydlík 2003 & Not RCT \\
\hline
\end{tabular}


(Continued)

\begin{tabular}{|c|c|}
\hline Nakamoto 2008 & Study participants did not have ESA resistance. \\
\hline Navarro 2002 & ESA not used in the control arm (compared erythropoietin to androgens) \\
\hline Odabas 2003 & Study participants did not have ESA resistance. \\
\hline Ono 1992 & Study participants did not have ESA resistance. \\
\hline Onoyama 1989 & Study participants did not have ESA resistance. \\
\hline Opatrnì 1998 & Study participants did not have ESA resistance. \\
\hline Panichi 2011 & Study participants did not have ESA resistance. \\
\hline Rao 2003 & Not RCT \\
\hline Richardson 2003 & Study participants did not have ESA resistance. \\
\hline Saxena 1997 & Study participants did not have ESA resistance. \\
\hline Sezer 2002 & Study participants did not have ESA resistance. \\
\hline Shahrbanoo 2008 & Study participants did not have ESA resistance. \\
\hline Sheashaa 2005 & Study participants did not have ESA resistance. \\
\hline Sorge-Haedicke 2001 & Study participants did not have ESA resistance. \\
\hline Taji 2004 & Study participants did not have ESA resistance. \\
\hline Tarng 1998 & Study participants did not have ESA resistance. \\
\hline Tarng 1999 & Study participants did not have ESA resistance. \\
\hline Tarng 2004 & Study participants did not have ESA resistance. \\
\hline Ursea 1995 & Study participants did not have ESA resistance. \\
\hline Usberti 2002a & Study participants did not have ESA resistance. \\
\hline Usberti $2002 b$ & Study participants did not have ESA resistance. \\
\hline Vaslaki 2006 & Study participants did not have ESA resistance. \\
\hline Wang 2000 & Study participants did not have ESA resistance. \\
\hline
\end{tabular}


(Continued)

Yang 2006

Study participants did not have ESA resistance.

ESA - Erythropoiesis-simulating agents; RCT - randomised control trial

\section{Characteristics of ongoing studies [ordered by study ID]}

Johnson 2008

Trial name or title The Hemoglobin elevation in Erythropoietin Resistance with Oxpentifylline (HERO Study)

Methods Investigator-initiated, prospective, double-blind, randomised, placebo-controlled phase 3 trial

Participants Inclusion criteria

- Adults aged $\geq 18$ years with CKD stage 4 or 5 (on dialysis or eGFR $<30 \mathrm{~mL} / \mathrm{min} / 1.73 \mathrm{~m}^{2}$ ) able to give informed consent and who have $\mathrm{Hb}$ concentration $<110 \mathrm{~g} / \mathrm{L}$ for at least 3 months in spite of EPO dose $\geq$ $200 \mathrm{IU} / \mathrm{kg} / \mathrm{wk}$ or DPO dose $\geq 1 \mu \mathrm{g} / \mathrm{kg} / \mathrm{wk}$ for at least 1 month. Revised criteria based on ESA-resistance index $\geq 1.0 \mathrm{IU} / \mathrm{kg} / \mathrm{wk} / \mathrm{g} \mathrm{Hb}$ for epoetin-treated patients and $\geq 0.005 \mu \mathrm{g} / \mathrm{kg} / \mathrm{wk} / \mathrm{g} \mathrm{Hb}$ for DPO-treated patients.

Exclusion criteria

- Patients with a history of psychological illness or condition which interferes with their ability to understand or comply with the requirements of the study

- Pregnancy or breastfeeding

- Known hypersensitivity to, or intolerance of, oxpentifylline or other methylxanthines, such as caffeine, theophylline or theobromine

- Active peptic ulcer disease

- Absolute or functional iron deficiency (ferritin $<100 \mu \mathrm{g} / \mathrm{L}$ and/or TSAT $<20 \%$ )

- Vitamin $\mathrm{B}_{12}$ or folate deficiency

- $\mathrm{PTH}>100 \mathrm{pmol} / \mathrm{L}$

- Serum aluminium $>2 \mu \mathrm{mol} / \mathrm{L}$

- Urea reduction ratio $<65 \%$ or single pool $\mathrm{Kt} / \mathrm{V}<1.0$ (HD patients) or total weekly $\mathrm{Kt} / \mathrm{V}<1.7$ (PD patients)

- Presence of systemic haematological disease (including antibody-mediated pure red cell aplasia) or known haemoglobinopathy

- Major surgery, infection, acute myocardial infarction or malignancy within the last 3 months

- Melatonin treatment, androgen therapy or blood transfusion within the previous month

- Vitamin C therapy $>100 \mathrm{mg} / \mathrm{d}$ or at a dose that has changed within the last 3 months

- Haemorrhagic stroke or severe haemorrhage within the last 3 months.

Interventions Intervention arm

- Oxpentifylline $400 \mathrm{mg}$ once daily

Control arm

- Identical placebo 1 tablet once daily

Outcomes

Primary: difference in $\mathrm{Hb}$ concentration between the oxpentifylline and control groups at the end of the 4 month study period

Interventions for erythropoietin-resistant anaemia in dialysis patients (Review) 
Johnson 2008 (Continued)

\begin{tabular}{|c|c|}
\hline Starting date & April 2008 \\
\hline Contact information & $\begin{array}{l}\text { Professor David Johnson, Level } 2 \text { ARTS Building, Princess Alexandra Hospital, Woolloongabba } 4102 \text { Queens- } \\
\text { land, Australia Tel: 61-7-31765080, Fax: 61-7-31765480, Email: David_Johnson@health.qld.gov.au }\end{array}$ \\
\hline \multicolumn{2}{|l|}{ Notes } \\
\hline \multicolumn{2}{|l|}{ NCT01526798 } \\
\hline Trial name or title & $\begin{array}{l}\text { Improvement of EPO-resistance in Hemodialysis Patients With Chronic Inflammation by High Cut-off } \\
\text { Hemodialysis (CIEPO-PILOT) }\end{array}$ \\
\hline Methods & Open-label RCT \\
\hline Participants & $\begin{array}{l}\text { Inclusion criteria } \\
\text { - ESKD treated with chronic HD for at least } 3 \text { months } \\
\text { - Treatment with high-flux dialyzers for at least } 3 \text { months } \\
\text { - Age } \geq 18 \text { years } \\
\text { - Receiving ESA to treat anaemia for at least } 3 \text { months } \\
\text { - Impaired ESA responsiveness as indicated by EPO resistance index }>\text { median of patients in study centre } \\
\text { - TSAT } \geq 20 \% \text { (last routine value prior to randomisation) } \\
\text { - Serum ferritin } \geq 100 \mathrm{ng} / \mathrm{mL} \text { (last routine value prior to randomisation) } \\
\text { Exclusion criteria } \\
\text { - Acute infection } \leq 4 \text { weeks prior to randomisation } \\
\text { - HIV or hepatitis infection } \\
\text { - Catheter } \\
\text { - Chronic liver disease } \\
\text { - Active cancer } \\
\text { - Known blood dyscrasia (paraprotein abnormalities) } \\
\text { - Known bleeding disorders } \\
\text { - Bleeding episode } \leq 12 \text { weeks prior to randomisation } \\
\text { - Blood/red cell transfusion } \leq 12 \text { weeks prior to randomisation } \\
\text { - Hypoalbuminaemia defined as serum albumin concentration below } 35 \mathrm{~g} / \mathrm{L} \text { (last routine value prior to } \\
\text { randomisation) } \\
\text { - Participation in another clinical interventional investigation } \\
\text { - Pregnancy } \\
\text { - Inability to give informed consent } \\
\text { - Planned transplantation within study period }+3 \text { months } \\
\text { - Planned interventions requiring hospitalisation }>1 \text { week }\end{array}$ \\
\hline
\end{tabular}

Interventions Intervention arm: Device: Theralite (high cut-off HD), HD with Theralite dialyzer alternating with standard high-flux dialyzer (Polyflux $\mathrm{H}$ )

Control arm: Device: Polyflux H, Conventional high-flux dialyzer

Outcomes $\quad$ EPO resistance index

Starting date March 2012

Interventions for erythropoietin-resistant anaemia in dialysis patients (Review) 


\section{NCT01526798 (Continued)}

Contact information Dr. Ugo Teatini, Azienda Ospedaliera Garbagnate Milanese Ospedale Bollate - Divisione Nefrologia e Dialisi, Bollate, Milan, Italy, 20021

Notes

CKD - chronic kidney disease; DPO - darbepoetin; EPO - erythropoietin; eGFR - estimated glomerular filtration rate; ESA - erythropoiesis-stimulating agent; $\mathrm{Hb}$ - haemoglobin; HD - haemodialysis; PD - peritoneal dialysis; PTH - parathyroid hormone; RCT randomised controlled trial; TSAT - transferrin saturation 
DATA AND ANALYSES

\section{Comparison 1. Clinical outcomes}

\begin{tabular}{|c|c|c|c|c|}
\hline Outcome or subgroup title & $\begin{array}{l}\text { No. of } \\
\text { studies }\end{array}$ & $\begin{array}{c}\text { No. of } \\
\text { participants }\end{array}$ & Statistical method & Effect size \\
\hline 1 Non-fatal cardiovascular events & 1 & & Risk Ratio (M-H, Random, 95\% CI) & Totals not selected \\
\hline 2 Hospitalisations & 1 & & Risk Ratio (M-H, Random, 95\% CI) & Totals not selected \\
\hline
\end{tabular}

\section{Comparison 2. Haematology and biochemistry results}

\begin{tabular}{|c|c|c|c|c|}
\hline Outcome or subgroup title & $\begin{array}{l}\text { No. of } \\
\text { studies }\end{array}$ & $\begin{array}{c}\text { No. of } \\
\text { participants }\end{array}$ & Statistical method & Effect size \\
\hline 1 Haemoglobin & 2 & & Mean Difference (IV, Random, 95\% CI) & Totals not selected \\
\hline 1.1 Vitamin $\mathrm{C}$ versus control & 1 & & Mean Difference (IV, Random, 95\% CI) & $0.0[0.0,0.0]$ \\
\hline $\begin{array}{l}\text { 1.2 High-flux versus low-flux } \\
\text { dialyser }\end{array}$ & 1 & & Mean Difference (IV, Random, 95\% CI) & $0.0[0.0,0.0]$ \\
\hline 2 Haematocrit & 1 & & Mean Difference (IV, Random, 95\% CI) & Totals not selected \\
\hline 3 Transferin saturation (TSAT) & 2 & & Mean Difference (IV, Random, 95\% CI) & Totals not selected \\
\hline 3.1 Vitamin $\mathrm{C}$ versus control & 1 & & Mean Difference (IV, Random, 95\% CI) & $0.0[0.0,0.0]$ \\
\hline $\begin{array}{l}\text { 3.2 High-flux versus low-flux } \\
\text { dialyser }\end{array}$ & 1 & & Mean Difference (IV, Random, 95\% CI) & $0.0[0.0,0.0]$ \\
\hline 4 Ferritin & 2 & & Mean Difference (IV, Random, 95\% CI) & Totals not selected \\
\hline 4.1 Vitamin $\mathrm{C}$ versus control & 1 & & Mean Difference (IV, Random, 95\% CI) & $0.0[0.0,0.0]$ \\
\hline $\begin{array}{l}\text { 4.2 High-flux versus low-flux } \\
\text { dialyser }\end{array}$ & 1 & & Mean Difference (IV, Random, 95\% CI) & $0.0[0.0,0.0]$ \\
\hline $\begin{array}{l}5 \text { Haemoglobin content in } \\
\text { reticulocytes }(\mathrm{CHr})\end{array}$ & 1 & & Mean Difference (IV, Random, 95\% CI) & Totals not selected \\
\hline 6 C-reactive protein & 2 & & Mean Difference (IV, Random, 95\% CI) & Totals not selected \\
\hline 6.1 Vitamin C versus control & 1 & & Mean Difference (IV, Random, 95\% CI) & $0.0[0.0,0.0]$ \\
\hline $\begin{array}{l}\text { 6.2 High-flux versus low-flux } \\
\text { dialyser }\end{array}$ & 1 & & Mean Difference (IV, Random, 95\% CI) & $0.0[0.0,0.0]$ \\
\hline
\end{tabular}

Comparison 3. ESA and IV iron doses

\begin{tabular}{lcccc} 
Outcome or subgroup title & $\begin{array}{c}\text { No. of } \\
\text { studies }\end{array}$ & $\begin{array}{c}\text { No. of } \\
\text { participants }\end{array}$ & Statistical method & Effect size \\
\hline 1 EPO dose & 1 & Mean Difference (IV, Random, 95\% CI) & Totals not selected \\
2 IV Iron & 1 & Mean Difference (IV, Random, 95\% CI) & Totals not selected \\
\hline
\end{tabular}

Interventions for erythropoietin-resistant anaemia in dialysis patients (Review) 


\section{Analysis I.I. Comparison I Clinical outcomes, Outcome I Non-fatal cardiovascular events.}

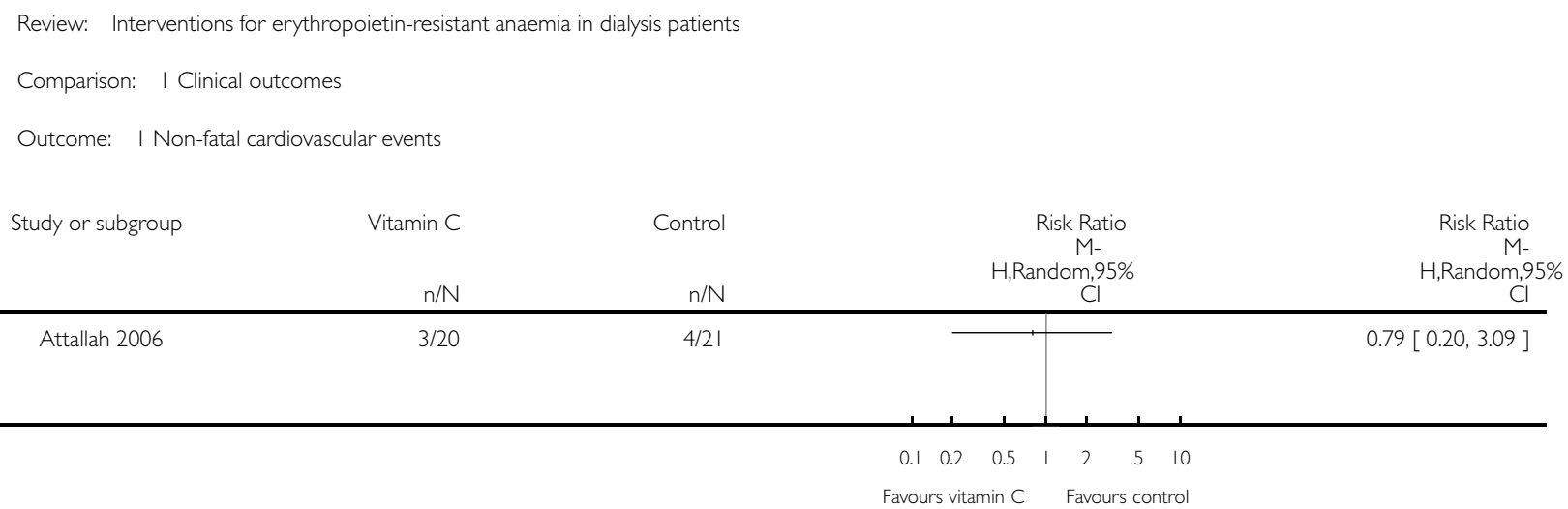

Analysis I.2. Comparison I Clinical outcomes, Outcome 2 Hospitalisations.

Review: Interventions for erythropoietin-resistant anaemia in dialysis patients

Comparison: I Clinical outcomes

Outcome: 2 Hospitalisations

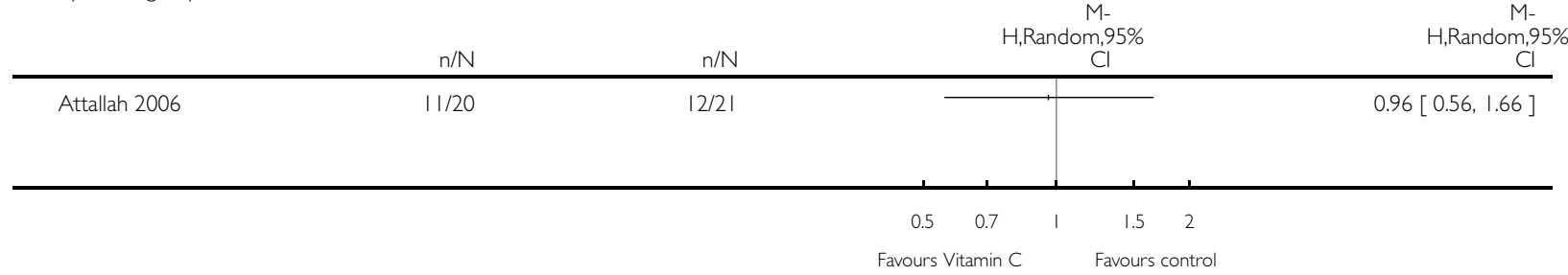




\section{Analysis 2.I. Comparison 2 Haematology and biochemistry results, Outcome I Haemoglobin.}

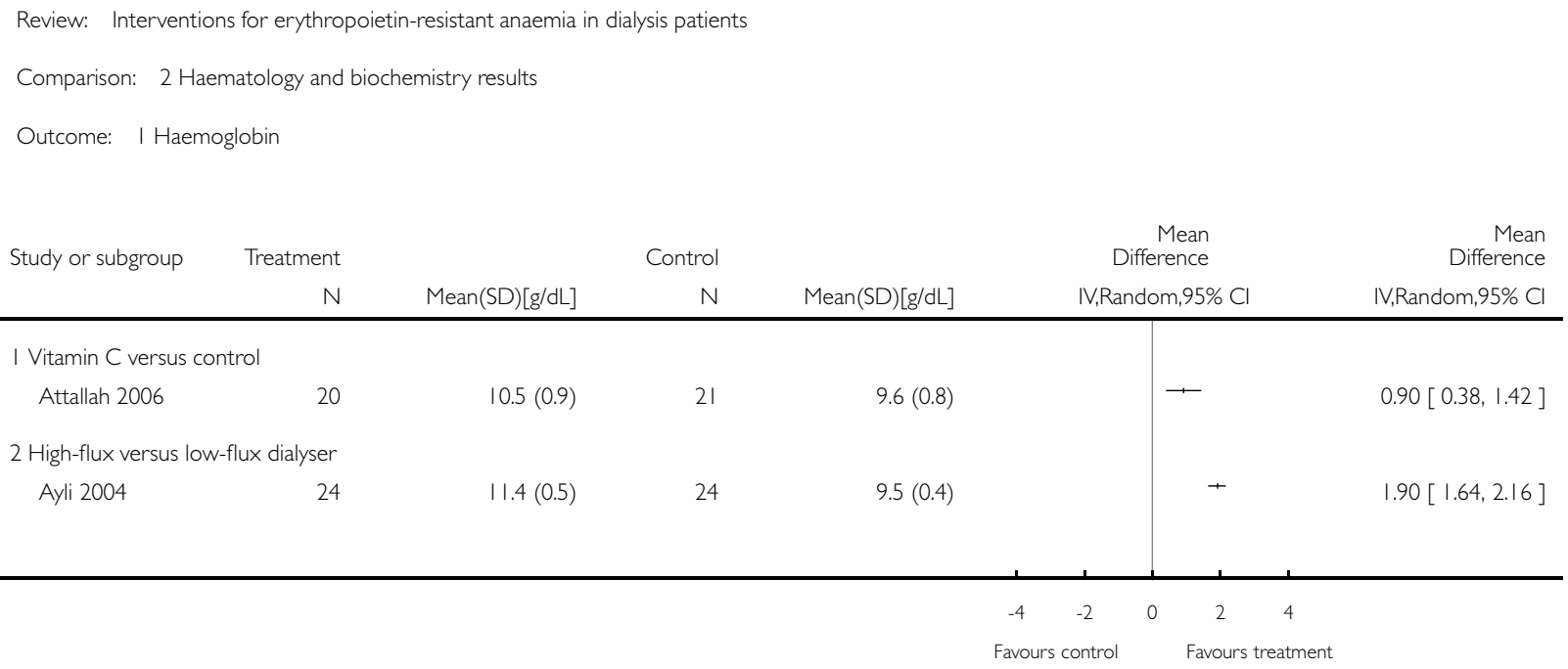

Analysis 2.2. Comparison 2 Haematology and biochemistry results, Outcome 2 Haematocrit.

Review: Interventions for erythropoietin-resistant anaemia in dialysis patients

Comparison: 2 Haematology and biochemistry results

Outcome: 2 Haematocrit

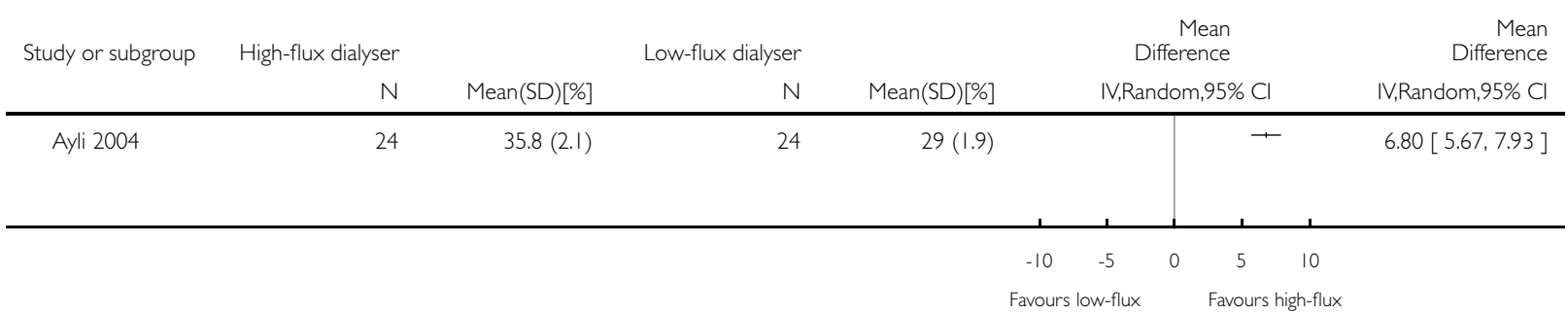


Analysis 2.3. Comparison 2 Haematology and biochemistry results, Outcome 3 Transferin saturation (TSAT).

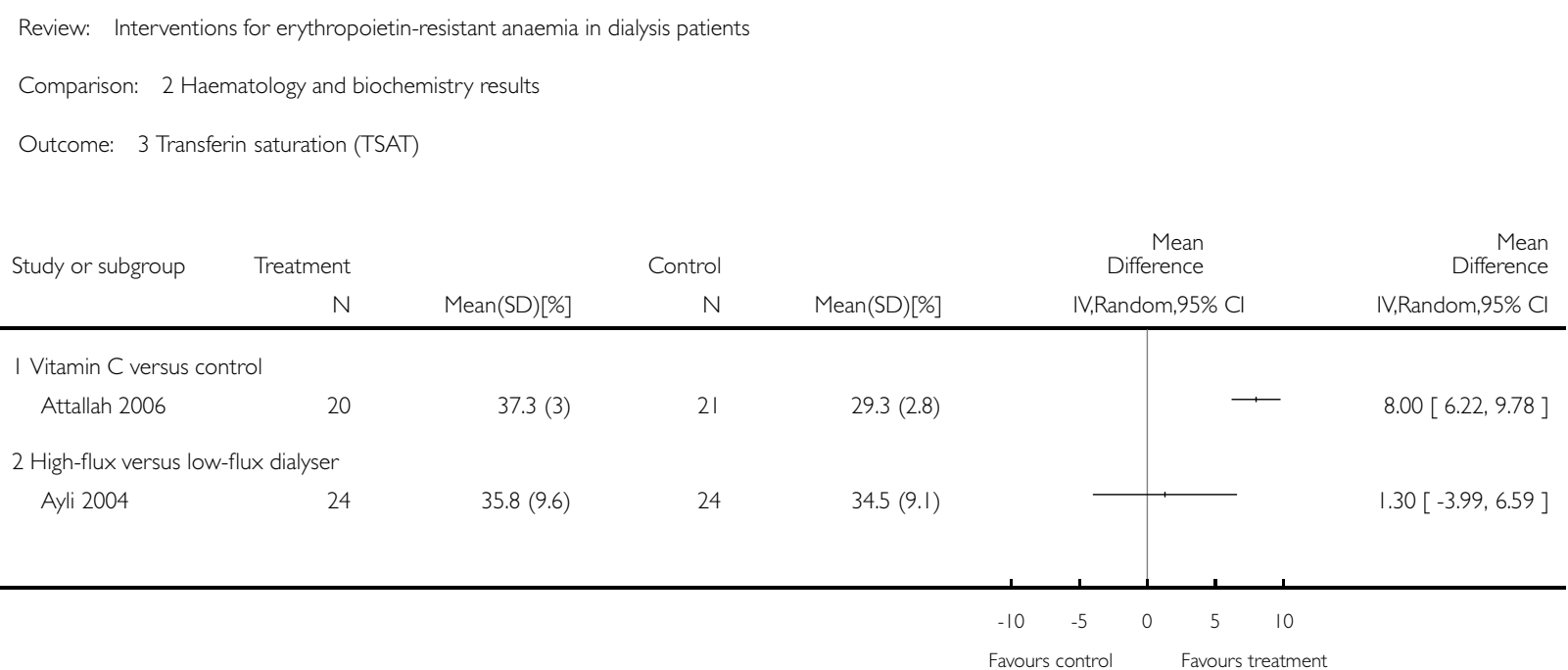

\section{Analysis 2.4. Comparison 2 Haematology and biochemistry results, Outcome 4 Ferritin.}

Review: Interventions for erythropoietin-resistant anaemia in dialysis patients

Comparison: 2 Haematology and biochemistry results

Outcome: 4 Ferritin

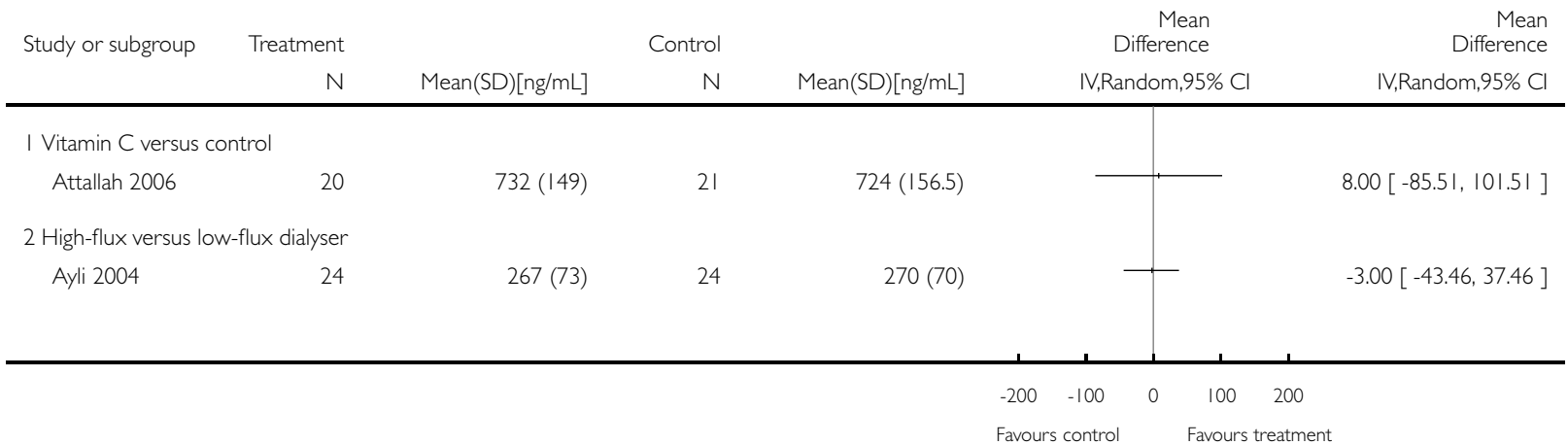


Analysis 2.5. Comparison 2 Haematology and biochemistry results, Outcome 5 Haemoglobin content in reticulocytes $(\mathrm{CHr})$.

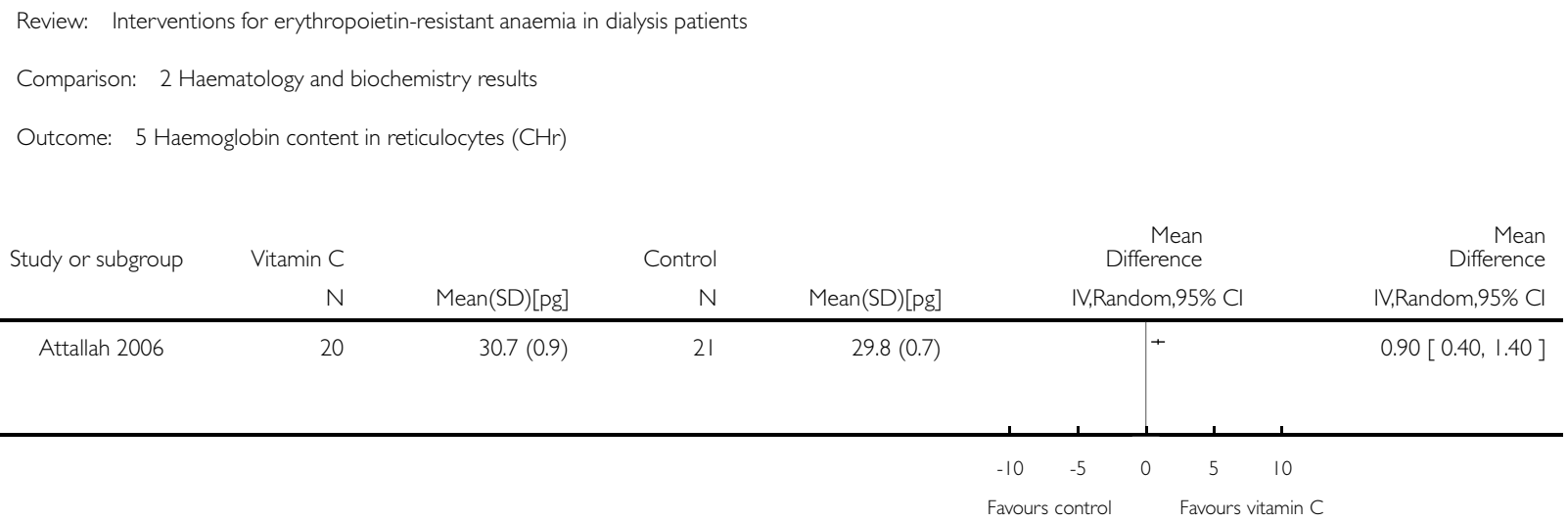

Analysis 2.6. Comparison 2 Haematology and biochemistry results, Outcome 6 C-reactive protein.

Review: Interventions for erythropoietin-resistant anaemia in dialysis patients

Comparison: 2 Haematology and biochemistry results

Outcome: 6 C-reactive protein

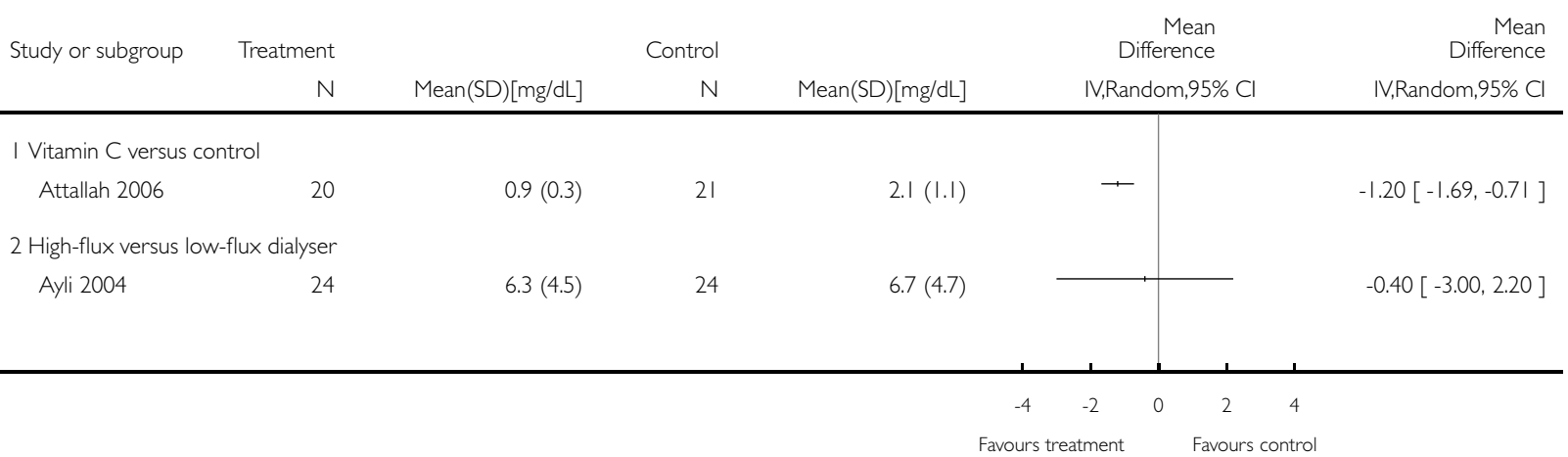




\section{Analysis 3.I. Comparison 3 ESA and IV iron doses, Outcome I EPO dose.}

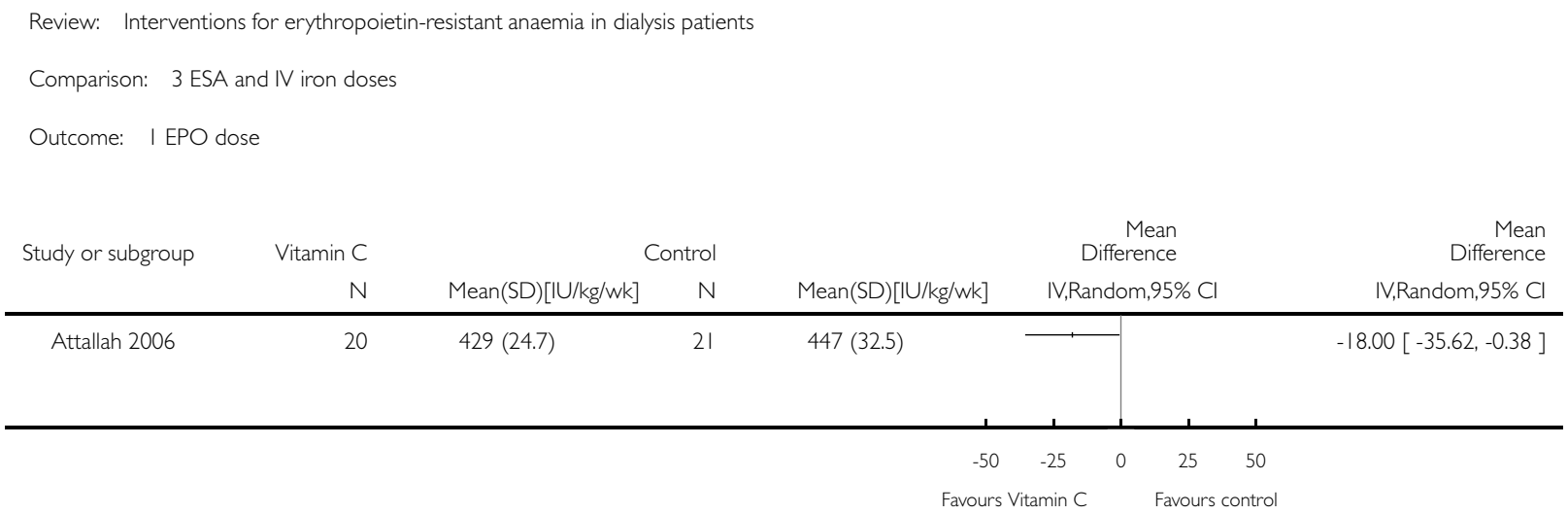

\section{Analysis 3.2. Comparison 3 ESA and IV iron doses, Outcome 2 IV Iron.}

Review: Interventions for erythropoietin-resistant anaemia in dialysis patients

Comparison: 3 ESA and IV iron doses

Outcome: $2 \mathrm{IV}$ Iron

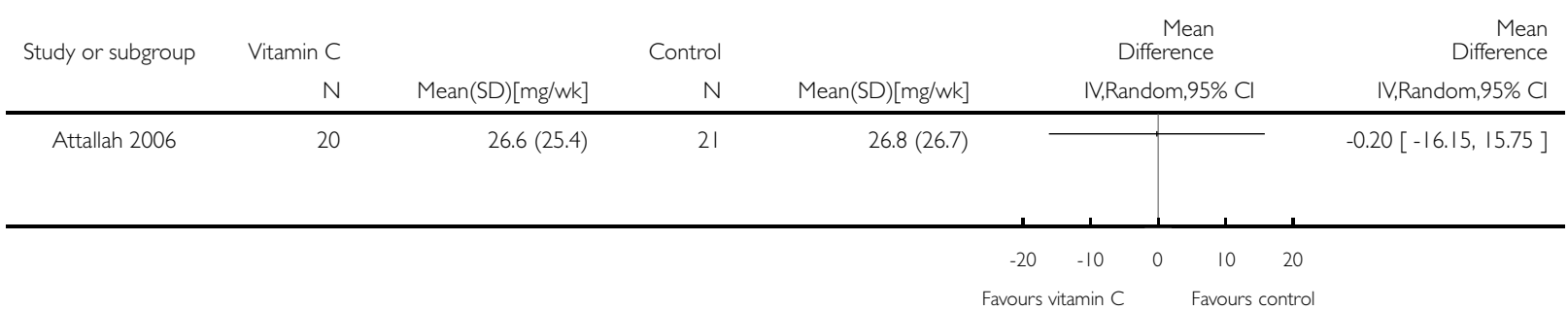


ADDITIONAL TABLES

Table 1. Current definitions of ESA resistance

\begin{tabular}{l|l}
\hline Author/study & Definition of ESA resistance \\
\hline KDOQI (KDOQI 2006) & Epoetin dose $>500 \mathrm{IU} / \mathrm{kg} / \mathrm{wk}$ \\
\hline Normal Haematocrit Cardiac Trial (Besarab 1998) & Epoetin dose $440 \mathrm{IU} / \mathrm{kg} / \mathrm{wk}$ in the normal haematocrit group \\
\hline CHOIR study (Szczech 2008) & Epoetin dose $>20,000 \mathrm{IU} / \mathrm{wk}$ \\
\hline Attallah 2006 & Epoetin dose $>450 \mathrm{IU} / \mathrm{kg} / \mathrm{wk}(\mathrm{IV})$ \\
\hline Ayli 2004 & Epoetin dose $>200 \mathrm{IU} / \mathrm{kg} / \mathrm{wk}(\mathrm{SC})$ \\
\hline Johnson 2008; HERO Study & Epoetin dose $\geq 200 \mathrm{IU} / \mathrm{kg} / \mathrm{wk}$ or darbepoetin dose $\geq 1 \mu \mathrm{gg} / \mathrm{kg} / \mathrm{wk}$ \\
\hline HERO Study (revised criteria) & $\begin{array}{l}\text { ESA-resistance index }(\mathrm{ERI}) \geq 1.0 \mathrm{IU} / \mathrm{kg} / \mathrm{wk} / \mathrm{g} \text { Hb for epoetin-treated patients } \\
\text { and } \geq 0.005 \mu \mathrm{g} / \mathrm{kg} / \mathrm{wk} / \mathrm{g} \text { Hb for darbepoetin-treated patients }\end{array}$ \\
\hline
\end{tabular}

Hb - haemoglobin

\section{A P P E N DICES}

\section{Appendix I. Electronic search strategies}

\begin{tabular}{l|l}
\hline Database & Search terms \\
\hline CENTRAL & $\begin{array}{l}\text { 1. dialysis:ti,ab,kw } \\
\text { 2. (hemodia* or haemodia*):ti,ab,kw }\end{array}$ \\
\hline & 3. (hemofiltration or haemofiltration):ti,ab,kw \\
4. (\#1 OR \#2 OR \#3) & 5. an*emia:ti,ab,kw \\
6. "iron overload":ti,ab,kw \\
7. (\#5 OR \#6) \\
8. erythropo*etin:ti,ab,kw \\
9. (erythropo*esis next stimulating next agent*):ti,ab,kw \\
10. (continuous next erythropo*esis next receptor next activator*):ti,ab,kw \\
11. EPO:ti,ab,kw \\
12. rhEPO:ti,ab,kw \\
13. epo*etin:ti,ab,kw \\
14. Eprex:ti,ab,kw
\end{tabular}



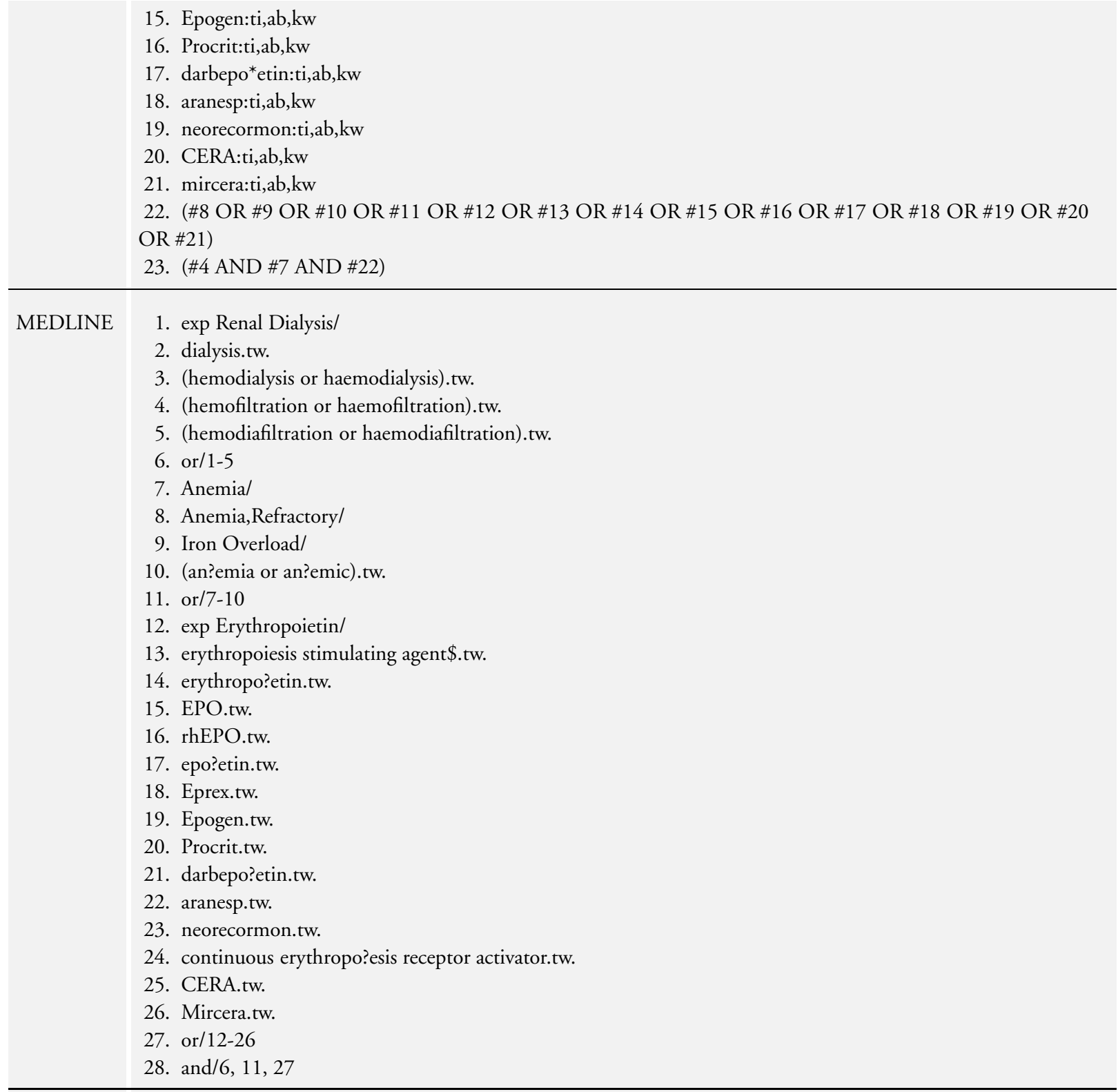

EMBASE
1. Anemia/
2. Refractory Anemia/
3. Iron Overload/
4. (an?emia or an?emic).tw.
5. or/1-4
6. Erythropoietin/
7. Recombinant Erythropoietin/
8. erythropo? esis stimulating agent $\$$.tw.
9. erythropo?etin.tw. 


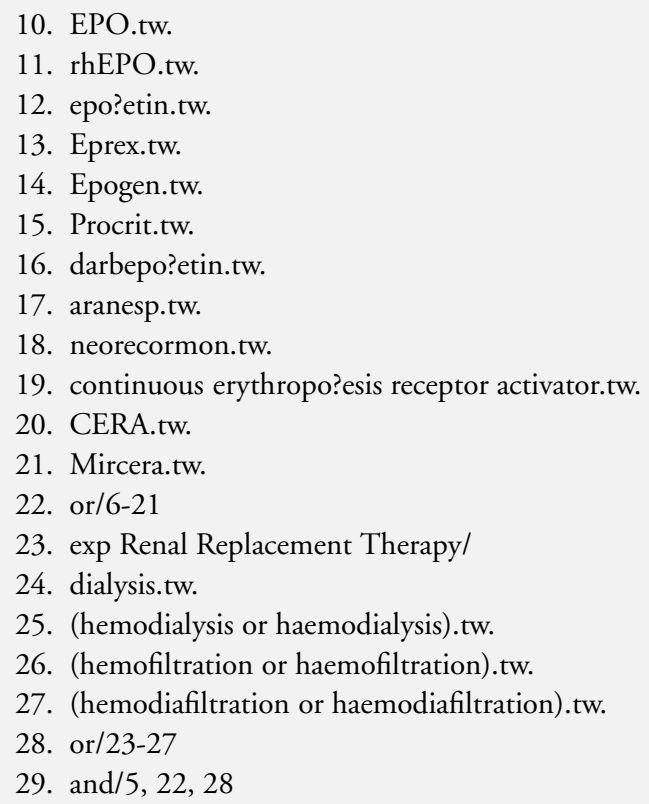

\section{Appendix 2. Risk of bias assessment tool}

\section{Potential source of bias}

\section{Random sequence generation}

Selection bias (biased allocation to interventions) due to inadequate generation of a randomised sequence

\section{Assessment criteria}

Low risk of bias: Random number table; computer random number generator; coin tossing; shuffling cards or envelopes; throwing dice; drawing of lots; minimization (minimization may be implemented without a random element, and this is considered to be equivalent to being random)

High risk of bias: Sequence generated by odd or even date of birth; date (or day) of admission; sequence generated by hospital or clinic record number; allocation by judgement of the clinician; by preference of the participant; based on the results of a laboratory test or a series of tests; by availability of the intervention

Unclear: Insufficient information about the sequence generation process to permit judgement

\section{Allocation concealment}

Low risk of bias: Randomisation method described that would not Selection bias (biased allocation to interventions) due to inadequate concealment of allocations prior to assignment allow investigator/participant to know or influence intervention group before eligible participant entered in the study (e.g. central allocation, including telephone, web-based, and pharmacy-controlled, randomisation; sequentially numbered drug containers of identical appearance; sequentially numbered, opaque, sealed en- 
High risk of bias: Using an open random allocation schedule (e.g. a list of random numbers); assignment envelopes were used without appropriate safeguards (e.g. if envelopes were unsealed or nonopaque or not sequentially numbered); alternation or rotation; date of birth; case record number; any other explicitly unconcealed procedure

Unclear: Randomisation stated but no information on method used is available

Blinding of participants and personnel

Performance bias due to knowledge of the allocated interventions by participants and personnel during the study

Low risk of bias: No blinding or incomplete blinding, but the review authors judge that the outcome is not likely to be influenced by lack of blinding; blinding of participants and key study personnel ensured, and unlikely that the blinding could have been broken

High risk of bias: No blinding or incomplete blinding, and the outcome is likely to be influenced by lack of blinding; blinding of key study participants and personnel attempted, but likely that the blinding could have been broken, and the outcome is likely to be influenced by lack of blinding

Unclear: Insufficient information to permit judgement

Blinding of outcome assessment

Detection bias due to knowledge of the allocated interventions by outcome assessors
Low risk of bias: No blinding of outcome assessment, but the review authors judge that the outcome measurement is not likely to be influenced by lack of blinding; blinding of outcome assessment ensured, and unlikely that the blinding could have been broken

High risk of bias: No blinding of outcome assessment, and the outcome measurement is likely to be influenced by lack of blinding; blinding of outcome assessment, but likely that the blinding could have been broken, and the outcome measurement is likely to be influenced by lack of blinding

Unclear: Insufficient information to permit judgement

\section{Incomplete outcome data}

Low risk of bias: No missing outcome data; reasons for missing Attrition bias due to amount, nature or handling of incomplete outcome data outcome data unlikely to be related to true outcome (for survival data, censoring unlikely to be introducing bias); missing outcome data balanced in numbers across intervention groups, with similar reasons for missing data across groups; for dichotomous outcome data, the proportion of missing outcomes compared with observed event risk not enough to have a clinically relevant impact on the intervention effect estimate; for continuous outcome data, plausible effect size (difference in means or standardized difference in 
means) among missing outcomes not enough to have a clinically relevant impact on observed effect size; missing data have been imputed using appropriate methods

High risk of bias: Reason for missing outcome data likely to be related to true outcome, with either imbalance in numbers or reasons for missing data across intervention groups; for dichotomous outcome data, the proportion of missing outcomes compared with observed event risk enough to induce clinically relevant bias in intervention effect estimate; for continuous outcome data, plausible effect size (difference in means or standardized difference in means) among missing outcomes enough to induce clinically relevant bias in observed effect size; 'as-treated' analysis done with substantial departure of the intervention received from that assigned at randomisation; potentially inappropriate application of simple imputation

Unclear: Insufficient information to permit judgement

\section{Selective reporting}

Reporting bias due to selective outcome reporting
Low risk of bias: The study protocol is available and all of the study's pre-specified (primary and secondary) outcomes that are of interest in the review have been reported in the pre-specified way; the study protocol is not available but it is clear that the published reports include all expected outcomes, including those that were pre-specified (convincing text of this nature may be uncommon)

High risk of bias: Not all of the study's pre-specified primary outcomes have been reported; one or more primary outcomes is reported using measurements, analysis methods or subsets of the data (e.g. subscales) that were not pre-specified; one or more reported primary outcomes were not pre-specified (unless clear justification for their reporting is provided, such as an unexpected adverse effect); one or more outcomes of interest in the review are reported incompletely so that they cannot be entered in a metaanalysis; the study report fails to include results for a key outcome that would be expected to have been reported for such a study

Unclear: Insufficient information to permit judgement

Low risk of bias: The study appears to be free of other sources of bias.

High risk of bias: Had a potential source of bias related to the specific study design used; stopped early due to some data-dependent process (including a formal-stopping rule); had extreme baseline imbalance; has been claimed to have been fraudulent; had some other problem 


\section{CONTRIBUTIONS OFAUTHORS}

- Write the protocol: SB, DF, EB, CH, DJ, IM, AC, VP

- Study selection: SB, CH, DJ

- Extract data from studies: SB, DJ

- Enter data into RevMan: SB, DJ

- Data analysis: SB, DF, EB

- Interpret the analysis: SB, DJ

- Draft the final review: SB, DJ

- Disagreement resolution: DF, EB, CH, IM, AC, VP

- Update the review: SB, DJ

\section{DECLARATIONSOF INTEREST}

- Dr Sunil V Badve, Elaine Beller and Daniel P Francis have no conflicts of interest to declare.

- Associate Professor Carmel Hawley has received consulting fees from Amgen and Janssen-Cilag; research grants from Amgen, Roche and Janssen-Cilag; and speakers' honoraria from Amgen.

- Professor Alan Cass is the recipient of a NHMRC Senior Research Fellowship. He has received speaker's honoraria and research grants from Janssen-Cilag, Amgen and Roche.

- Associate Professor Vlado Perkovic has received speakers' honoraria from Roche and research grants from Johnson and Johnson Pharmaceutical Research \& Development and Roche.

- Professor Iain C. Macdougall has received consultant fees, research grants, and/or lecture fees from Amgen, Ortho biotech, Roche, Affymax, Takeda, Hospira, and Sandoz.

- Professor David Johnson has received speakers' honoraria, consultancy fees and research grants from Janssen-Cilag, Amgen and Roche. He has received fees for organising education from Amgen and Janssen-Cilag. He has received consultancy fees from Pfizer. He is also the Principal Investigator in the HERO Trial, a randomised, double-blind, placebo-controlled trial of oxpentifylline in the treatment of erythropoietin stimulating agent hyporesponsiveness. Professor Alan Cass and Associate Professor Carmel Hawley are the members of the Trial Management Committee of the HERO trial. 


\section{SOURCES OF SUPPORT}

\section{Internal sources}

- Australasian Kidney Trials Network, School of Medicine, University of Queensland, Australia.

- Princess Alexandra Hospital, Woolloongabba, QLD, Australia.

\section{External sources}

- No sources of support supplied

\section{DIFFERENCES BETWEEN PROTOCOLANDREVIEW}

In the protocol for this review, we had planned that one of our inclusion criteria would define ESA resistance. Evidence of ESAresistance, defined as failure to achieve or maintain target range haemoglobin/haematocrit levels in spite of appropriate doses of the ESA (erythropoietin dose $\geq 450 \mathrm{U} / \mathrm{kg} / \mathrm{wk}$ intravenous administration or $\geq 300 \mathrm{U} / \mathrm{kg} / \mathrm{wk}$ for subcutaneous administration or darbepoetin dosage $\geq 1.5 \mu \mathrm{g} / \mathrm{kg} / \mathrm{wk}$ ) (KDOQI 2001; Locatelli 2004) was to be applied. This inclusion criterion was amended because only one eligible study was found.

\section{INDEX TERMS}

\section{Medical Subject Headings (MeSH)}

${ }^{*}$ Renal Dialysis; Anemia [blood; *drug therapy]; Drug Resistance; Erythropoiesis [* drug effects]; Erythropoietin [*administration \& dosage]; Hematocrit; Kidney Failure, Chronic [*complications; therapy]; Randomized Controlled Trials as Topic

\section{MeSH check words}

Humans 